\title{
BURMESE JADE: THE INSCRUTABLE GEM
}

By Richard W. Hughes, Olivier Galibert, George Bosshart, Fred Ward, Thet 0o, Mark Smith, Tay Thye Sun, and George E. Harlow

The jadeite mines of Upper Burma (now Myanmar) occupy a privileged place in the world of gems, as they are the principal source of top-grade material. This article, by the first foreign gemologists allowed into these important mines in over 30 years, discusses the history, location, and geology of the Myanmar jadeite deposits, and especially current mining activities in the Hpakan region. Also detailed are the cutting, grading, and trading of jadeite - in both Myanmar and China — as well as treatments. The intent is to remove some of the mystery surrounding the Orient's most valued gem.

\section{ABOUT THE AUTHORS}

Mr. Hughes (rubydick@ruby-sapphire.com) is an author, gemologist, and webmaster at Pala International, Fallbrook, Califomia. Mr. Galibert (FGA, hons.; ING, AG) is a gemologist and Hong Kong-based dealer in colored stones and pearls. Mr. Bosshart is chief gemologist, Research and Development, at the Gübelin Gem Lab, Luceme, Switzerland. Mr. Ward, a gemologist, writer, and photographer, owns Gem Book Publishing,

Bethesda, Maryland. Dr. Thet Oo is a gemologist and Yangon-based dealer in colored stones. Mr. Smith is a gemologist and Bangkok-based dealer in colored stones. Dr. Tay is president of Evin Gems and Far Eastem Gemmological Lab of Singapore. Dr. Harlow is curator of Gems and Minerals at the American Museum of Natural History, New York City.

Please see acknowledgments at the end of the article.

Gems \& Gemology, Vol. 36, No. 1, pp. 2-26 (c) 2000 Richard W. Hughes
If jade is discarded and pearls destroyed, petty thieves will disappear, there being no valuables left to steal.

- From a dictionary published during the reign of Emperor K'ang Hsi (1662-1722 AD) , as quoted by Gump, 1962

$\mathcal{P}$ erhaps no other gemstone has the same aura of mystery as Burmese jadeite. The mines' remote jungle location, which has been off-limits to foreigners for decades, is certainly a factor. Because of the monsoon rains, this area is essentially cut off from the rest of the world for several months of the year, and guerrilla activities have plagued the region since 1949 (Lintner, 1994).

But of equal importance is that jade connoisseurship is almost strictly a Chinese phenomenon. People of the Orient have developed jade appreciation to a degree found nowhere else in the world, but this knowledge is largely locked away in non-Roman-alphabet texts that are inaccessible to most Westerners, adding further to jadeite's inscrutable reputation. The mines of Burma (now Myanmar*) are the primary working deposits for the most prized gem in the Far East (figure 1), a stone exceeded in price only by diamond.

This article will draw back the curtain on this enigmatic gem, revealing the manner in which Burmese jadeite is mined, traded, graded, cut, treated, and faked. Since the major gemological features of jade have already been extensively covered in the literature (Hobbs, 1982; Fritsch et al., 1992; Wang, 1994), emphasis here will be on these lesserknown aspects. An understanding of jadeite is not limited to the technical or exacting, but it also requires a feeling for the cultural, textural, and ephemeral qualities that make the study of jade unlike any other in the world of gemstones.

Jade has a rich history in the Orient, especially China (Box A). Historically, the term jade was applied to any of a number of ornamental materials that could be carved, but most importantly amphibole jade, or nephrite. The rich green material subsequently found in Myanmar proved to be composed primarily of a different mineral (a pyroxene) and 
Figure 1. "Windows" cut into this otherwise undistinguished boulder from the Myanmar Jade Tract reveal the presence of a rich green in the jadeite beneath the skin. Boulders such as this are the source of the fine green, orangered, and lavender cabochons that are much sought-after in China and elsewhere. The bowl is approximately $6 \mathrm{~cm}$ wide $\times 5 \mathrm{~cm}$ high. The cabochons measure approximately $15 \times 19 \mathrm{~mm}$ (green), $13 \times 18 \mathrm{~mm}$ (orange-red), and $10 \times 14$ mm (lavender). Courtesy of Bill Larson and Pala International; photo (C) Harold e Erica Van Pelt.

was named jadeite (see Box B). In this article, jade encompasses both jadeite and nephrite in those instances where the general carving material is being referenced, but jadeite or jadeite jade will be used to refer to the rock that is predominantly jadeite, where appropriate.

Although jadeite deposits are found throughout the world (Guatemala, Japan, Russia, and California), Myanmar remains the primary source of top-grade material. The Hpakan jadeite region (figure 2) is one of the wildest, least-developed areas of the country. Until the authors' first trip, in 1996, no foreign gemologists had visited the mines since Edward Gübelin in 1963 (Gübelin, 1964-65, 1965a and b).

\footnotetext{
*In the local vernacular, the country has always been called Myanmar. The English name was officially changed to Myanmar in 1988. Although many people continue to refer to it as Burma, in this article, the country will be referred to by its official name Myanmar.
}

One European known to have traveled in the general area was Swedish journalist Bertil Lintner, who in 1985-86 made an epic journey through rebel-held areas of northern Myanmar, including the region surrounding Hpakan (see, e.g., Lintner, 1996). But he was unable to visit the mines themselves.

On February 24, 1994, a formal cease-fire was signed between the Myanmar government and the main rebel group, the Kachin Independence Army (Lintner, 1996). In June 1996, RWH, OG, MS, and TO made a brief trip to Hpakan. To give some idea of the sensitivity of this area, months were needed to obtain permission, with final approval coming from the second-highest-ranking general in the ruling SLORC (State Law and Order Restoration Committee) military junta. RWH again visited the mines in March 1997, this time accompanied by FW and a German film crew led by Bangkok-based journalist Georg Muller. This trip included a visit to Tawmaw. In November 1997, GB and TO paid a 


\section{BoX A: JADE-HEAVEN's STONE}

More than 2,500 years ago, Gautama Buddha recognized that much of life involves pain and suffering. Consequently, few of us here on Earth have been provided with a glimpse of heaven. Instead, we mostly dwell in hell. But for the Chinese, there is a terrestrial bridge between heaven and hell-jade.

While gems such as diamond entered Chinese culture relatively recently, the history of jade (at the time, nephrite or another translucent material used for carving) stretches back thousands of years. In ancient China, nephrite jade was used for tools,

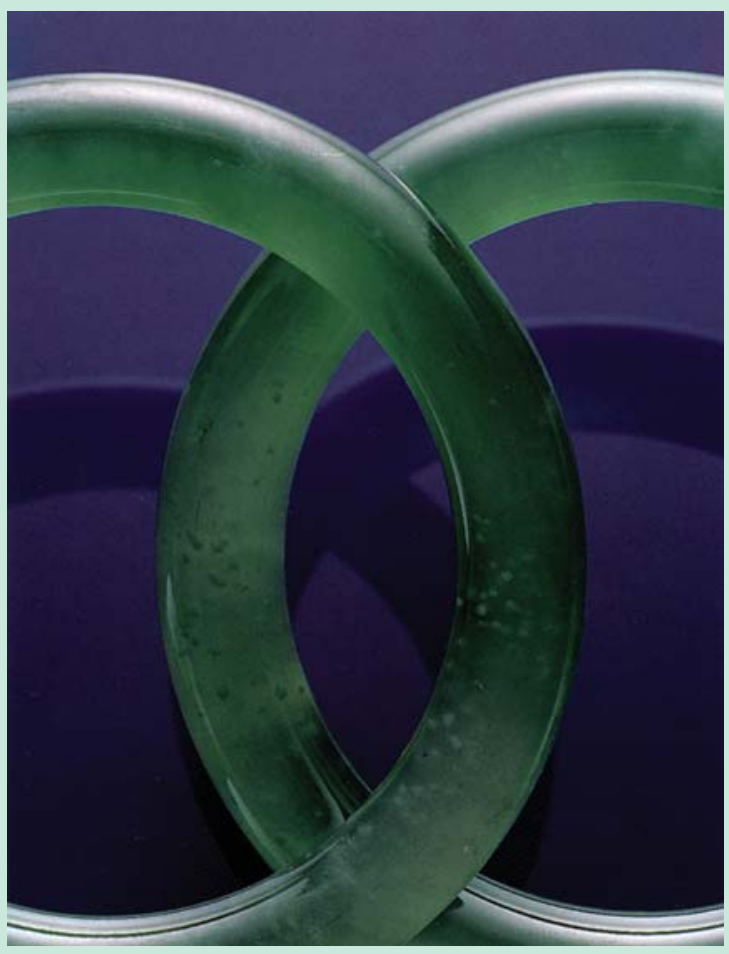

weapons, and ornaments (Hansford, 1950). Jade's antiquity contributes an aura of eternity to this gem. Confucius praised jade as a symbol of righteousness and knowledge.

$\mathrm{Yu}$ (玉), the Chinese word for jade, is one of the oldest in the Chinese language; its pictograph is said to have originated in $2950 \mathrm{BC}$, when the transition from knotted cords to written signs supposedly occurred. The pictograph represents three pieces of jade (三), pierced and threaded with a string $(I)$; the dot was added to distinguish it from the pictograph for "ruler" (Goette, n.d.).

To the Chinese, jade was traditionally defined by its "virtues," namely a compact, fine texture, tremendous toughness and high hardness, smooth and glossy luster, along with high translucency and the ability to take a high polish (Wang, 1994). But they also ascribe mystical powers to the stone. Particularly popular is the belief that jade can predict the stages of one's life: If a jade ornament appears more brilliant and transparent, it suggests that there is good fortune ahead; if it becomes dull, bad luck is inevitable.

Jadeite (figure A-1) is a relatively recent entry to the jade family. While some traditionalists feel that it lacks the rich history of nephrite, nevertheless the "emerald" green color of Imperial jadeite is the standard by which all jades-including nephrite-are judged by most Chinese enthusiasts today.

Figure A-1. Although nephrite jade is China's original "Stone of Heaven," fine jadeite, as in this matched pair of semi-transparent bangles (53.4 $\mathrm{mm}$ in interior diameter, $9.8 \mathrm{~mm}$ thick), is the most sought-after of jades in the Chinese community today. Photo courtesy of and (c) Christie's Hong Kong and Tino Hammid. further visit to the Hpakan area, including a trip to Kansi and Maw Sit. Most recently, in January and February 2000, GEH visited the Nansibon jadeite deposits in the historic Hkamti area, which are located approximately $60 \mathrm{~km}$ northwest of Hpakan.

\section{HISTORY}

The entire pre-1950s occidental history of Myanmar's jade mines is covered in Hughes (1999). With the exception of a brief mention in Griffith (1847), virtually the only account in English of the early history of jadeite in then-Burma is that of a Mr. Warry of the Chinese Consular Service. Hertz's Burma Gazetteer: Myitkyina District (1912) quotes at length from his 1888 report, and the historical sections of virtually all other accounts (see, e.g., Chhibber, 1934b; Keller, 1990) are based on Warry. The following also is based on Warry's report, as quoted by Hertz (1912).

Until at least the 13th century, "jade" in China was generally nephrite, a tough, white-to-green amphibole rock that was a favorite of stone carvers. The most important source was south of Hotan (Khotan) in the Kunlun mountains of western China; here, nephrite was recovered from both the White Jade and Black Jade rivers (Gump, 1962). Sometime in the 13th century, according to local lore as reported by Warry (Hertz, 1912), a Yunnan 


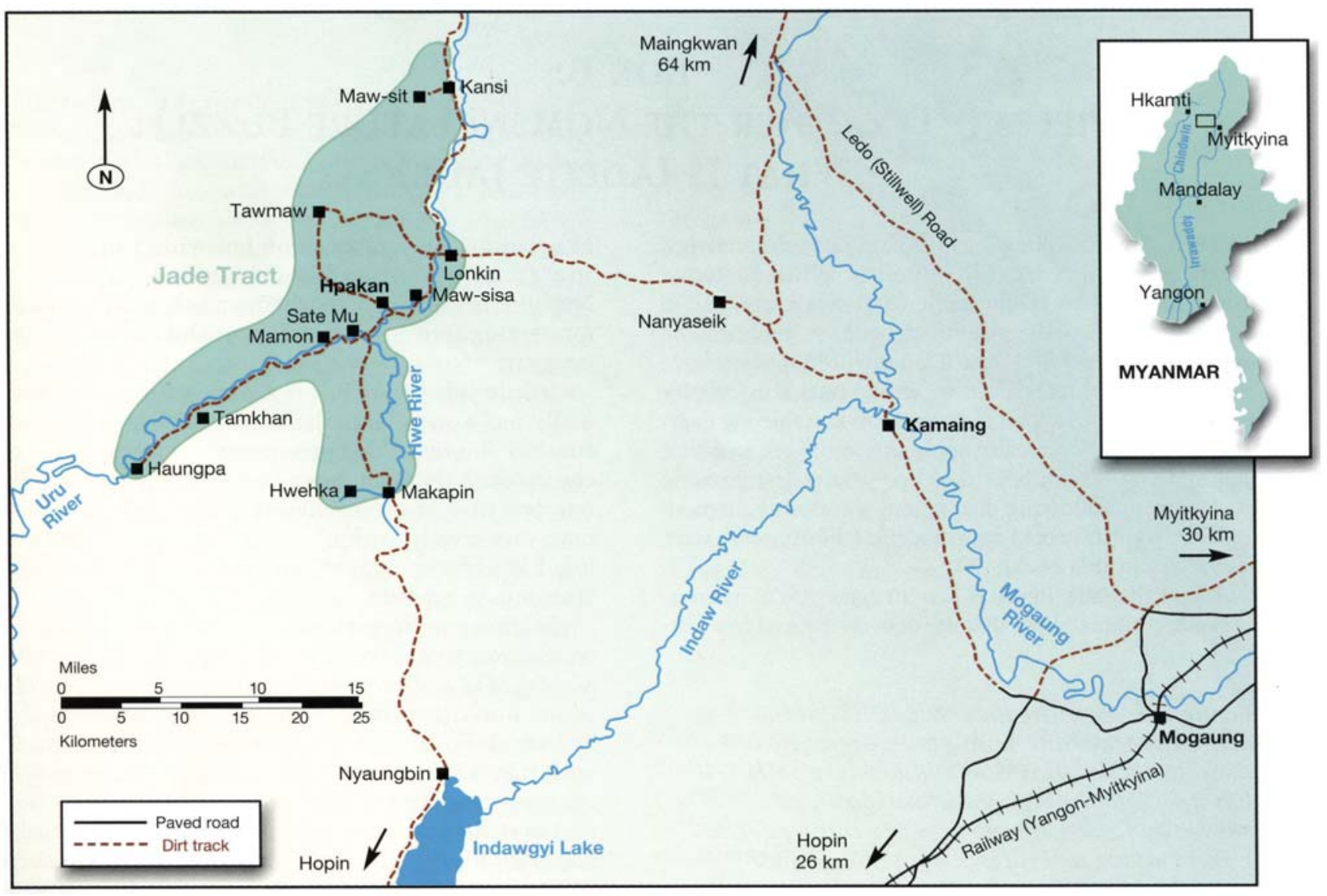

Figure 2. Hpakan is the center of the jadeite mining district (or central Jade Tract) in north-central Myanmar. There are two main routes into the Hpakan region, one from Mogaung and the other from Hopin. Adapted by R.W. Hughes and G. Bosshart from Hind Co. Map (1945).

trader traveling through what is now northern Myanmar picked up a boulder to balance the load on his mule. When it was broken open, the brownskinned rock revealed a vivid, "emerald" green material with the toughness of nephrite. The Chinese were captivated by this stone.

Also according to Warry, the Yunnan government sent expeditions to find the source of this unusual material in the 13th and 14th centuries, but they were unsuccessful. Although occasional small pieces of green jadeite would appear in China over the next 500 years, their origin remained a mystery until the late 18th century.

Enter the Dragon. In 1784, Emperor Qianlong (who reigned from 1736 to 1796) extended China's jurisdiction into northern Myanmar, where Chinese adventurers soon discovered the source of the green stone. From the late 18th century on, considerable amounts of jadeite were transported to Beijing and the workshops of China's foremost jade carvers.
Emperor Qianlong preferred the rich hues of this "new" jade (jadeite), and soon the finest semi-transparent rich green fei-ts'ui ("kingfisher") material came to be known as "Imperial jade" (Hertz, 1912).

A well-established route for jadeite from Myanmar to China existed by 1798 . Although political and other circumstances forced several alterations in the original route, the "jade road"-from Hpakan through Baoshan and Kunming in Yunnan—operated until World War II.

The Rise of Hong Kong as a Trading Center. With the arrival of a communist regime in China following the Second World War, materialistic symbols such as jade fell out of favor. For the most part, the jadeite trade moved to Hong Kong, where carvers emigrated from Beijing and Shanghai.

In the 1950s, jadeite dealers went directly to Hong Kong, or had their stones relayed for sale there via Yunnanese and Cantonese colleagues. Jadeite auctions were organized in hotels such as the four-story 


\section{Box B: \\ Piecing Together the Nomenclature Puzzle: WHAT IS JADEITE JADE?}

In 1863, French mineralogist Alexis Damour analyzed bright green jades from then-Burma. When he found these samples to be different from what was called Chinese jade (usually amphibole jade, or nephrite), he named the mineral jadeite (Damour, 1863). Although, as noted in the text, Chinese enthusiasts use jade for many ornamental materials that are suitable for carving, gemologists typically apply the term jade to either nephrite (an amphibole rock) or jadeite (a pyroxene rock). In the following discussion, we also distinguish jadeite jade (the rock) from jadeite (the mineral with nominal formula $\mathrm{NaAlSi}_{2} \mathrm{O}_{6}$ ).

Nephrite jade (figure B-1) is an aggregate of micronwide amphibole fibers that are densely packed in a felt-

Figure B-1. Nephrite jade, which lies in the actinolite-tremolite series, is an aggregate of densely packed amphibole fibers. It usually has a distinctive greasy surface luster, as shown by these Chinese nephrite carvings. The larger carving measures $5.7 \mathrm{~cm}$ in diameter; photo by Maha Tannous.

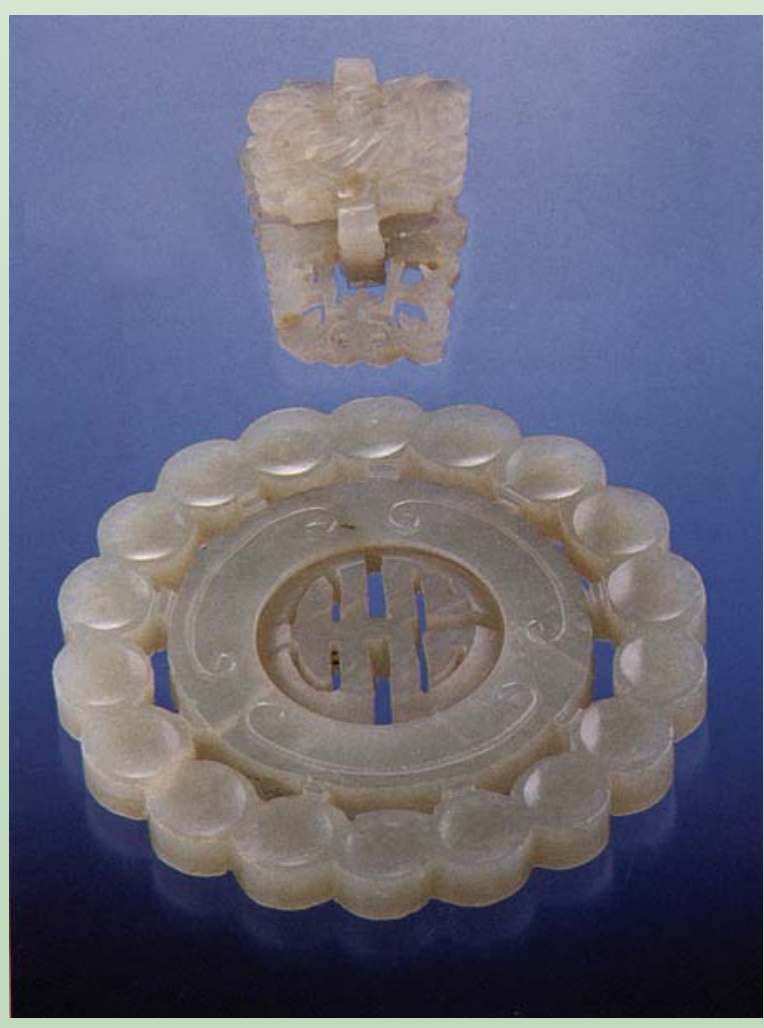

like texture. The composition lies within the actinolite-tremolite series $\left[\mathrm{Ca}_{2}\left(\mathrm{Mg}_{2} \mathrm{Fe}^{2+}\right)_{5} \mathrm{Si}_{8} \mathrm{O}_{22}(\mathrm{OH})_{2}\right]$. Nephrite is supremely tough among all rocks, suitable for carving into intricate shapes while retaining its integrity.

Jadeite jade (figure B-2) is a compact rock that generally has a more granular texture than nephrite. It consists of interlocking prismatic to "feathery" pyroxene crystals that can range in length from about 10 microns to over a centimeter, with a grain size that may vary greatly within a small area. Rarely, jadeite jade has a fibrous texture, but such jadeite will still be coarser than nephrite.

Jadeitic pyroxene in jade typically is not pure: It contains varying percentages of the pyroxenes diopside $\left(\mathrm{CaMgSi}_{2} \mathrm{O}_{6}\right)$ and/or kosmochlor $\left(\mathrm{NaCrSi}_{2} \mathrm{O}_{6}\right)$ - as well as the iron-rich pyroxenes hedenbergite $\left(\mathrm{CaFe}^{2+} \mathrm{Si}_{2} \mathrm{O}_{6}\right)$ and aegirine $\left(\mathrm{NaFe}^{3+} \mathrm{Si}_{2} \mathrm{O}_{6}\right)$-in solid-solution mixtures with jadeite. Nearly pure kosmochlor (formerly called ureyite; first detected in meteorites) also may be present in some dark green jades. To qualify as jadeite jade petrologically, jadeitic pyroxene should constitute over $90 \%-95 \%$ of the rock; otherwise, it is just a jadeiterich rock and will probably not have the toughness of jade. The other minerals in jadeite jade from Myanmar are sodic amphibole (compositions vary between eckermannite, glaucophane, richterite, and edenite), albite, analcime, tremolite, (ilmeno-) rutile, clinochlore, banalsite, and chromite (see, e.g., Harlow and Olds, 1987; Htein and Naing, 1994 and 1995).

Jadeite (the mineral) is allochromatic; that is, it is transparent and colorless when pure. But as jade, it generally appears white due to light scattering from fractures, openings on grain boundaries, and tiny aqueous fluid inclusions. However, even white jadeite jade is commonly polymineralic, in that it is intergrown with minor albite and analcime, which introduce additional internal light scattering from the changes in refractive index across grain boundaries. A few jadeite jade colors are caused by mineral staining on grain boundaries-11) hydrous iron oxides for red- to orangebrown, (2) an iron compound (iron-rich clay?) for some dark green streaks, and (3) graphite for some gray-toblack jadeite jades.

However, most colors of jadeite are due to substitutions of transition metal ions for the fundamental $\mathrm{Al}^{3+}$ and minor $\mathrm{Mg}^{2+}$ (from diopside content) in jadeitic pyroxene. "Imperial" green, the most highly valued jade color (which is not duplicated in nephrite), is produced by $\mathrm{Cr}^{3+}$; only a very small percentage of this 
minor element is required to induce the vivid color. "Grassy" greens are the result of either $\mathrm{Fe}^{2+}$ or $\mathrm{Fe}^{3+}$ as the essential chromophore, although mixed $\mathrm{Fe}^{2+}$ and $\mathrm{Fe}^{3+}$ produces blue-green, bluish black, and blue-black jadeite; the darkest colors form in "jadeites" that have a few weight percent total iron oxide and are closer to half-jadeite/half-augite or the pyroxene called omphacite (Harlow and Sorensen, in press). Lavender jadeite is attributed to $\mathrm{Fe}^{2+}-\mathrm{O}-\mathrm{Fe}^{3+}$ intervalence charge transfer in nearly pure jadeite (Rossman, 1974; Ponahlo, 1999). The color of aggregates of jadeite and sodic amphiboles has been termed "leek" green (in contrast to the "spinach" green of nephrite).

It is not uncommon for some jadeite to be partly replaced by fibrous tremolite or actinolite (Tröger, 1967; Ou Yang, 1993) in the course of late-stage metasomatism. These polymineralic jades are polychromatic, usually white with gray-green to blackish green specks or streaks. Rarely, they appear green with fairly even color distribution. The designation of mixtures of jadeite and amphibole as "szechenyite" has been discredited (Deer et al., 1963).

Maw-sit-sit, mentioned as hmaw sit sit by Chhibber (1934b) and first described by Gübelin $(1965 \mathrm{a}-\mathrm{c})$, is an ornamental rock that is a mottled, highly variegated intergrowth of white albite, yellowish white Mg-chlorite (clinochlore), green-black kosmochlor, chromian jadeite, and green eckermannitic amphibole (figure B-3). The latter three minerals are commonly associated with corroded black chromite $\left[(\mathrm{Fe}, \mathrm{Mg}) \mathrm{Cr}_{2} \mathrm{O}_{4}\right]$ crystals, from which the chromophoric $\mathrm{Cr}^{3+}$ ion is derived (Harlow, unpublished data; Hänni and Meyer, 1997; Harlow and Olds, 1987; Mével and Kiénast, 1986). The interstitial material (colorless, yellow, or white) within the remaining tiny crevices and cavities consists of serpentine or zeolite (thomsonite?). Maw-sit-sit is a "cousin" of jade, but because some samples contain compact centimeter-sized regions of chromian jadeite, a clear distinction from jadeite jade can be difficult.

Chloromelanite has been used to describe a dark green to black variety of jadeite (Tröger, 1967; Hobbs, 1982); mineralogically, it is a solid solution of roughly equal amounts of jadeite, diopside, and aegirine (Jackson, 1997). The term is used rather loosely by traders, who typically apply it to any dark green to black jade-like material. We discourage use of the term chloromelanite because the traditional trade usage conflicts with modern knowledge of its composition. Indeed, the name has already been discredited mineralogically, in favor of referring to the particular pyroxenes present (omphacite or aegirine-augite; Morimoto et al., 1988).

From a gemological standpoint, what does all this mean? Jadeite jade is essentially a rock with a variable
Figure B-2.

"True" jadeite jade contains at least $90 \%$ jadeitic pyroxene in a rock that is typically more granular than nephrite. Note the vitreous surface luster of these translucent jadeite beads, which range from 9 to $10.5 \mathrm{~mm}$ in diameter. Photo courtesy of and (c) Christie's Hong Kong and Tino Hammid.

composition. Although some have suggested a classification scheme for jadeite based on variations in composition or structure (Ou Yang, 1993; Wang, 1994), this is impractical for gemology because of the sophisticated equipment that would be needed to distinguish the various categories.

Figure B-3. A "cousin" to jade, maw-sit-sit is an attractive ornamental stone that is an intergrowth mainly of albite, clinochlore, kosmochlor, chromian jadeite, and eckermannitic amphibole. These two maw-sit-sit cabochons weigh $9.87 \mathrm{ct}$ (oval) and $8.48 \mathrm{ct}$. Courtesy of Pala International; photo (c) Harold e) Erica Van Pelt.

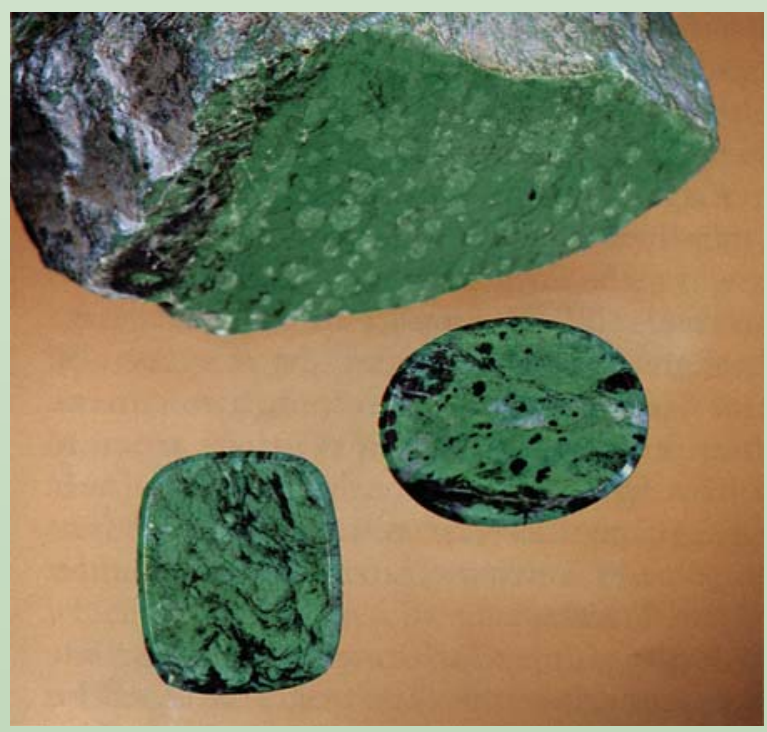


Tai Tung Hotel (Benjamin S. Y. So, pers. comm., 1997). Starting in 1967, auctions were organized by the Hong Kong Jewellery and Jade Manufacturers Association (formerly Hong Kong Jade and Stone Manufacturers Association).

With the introduction of free-market reforms in China in the early 1980s, the markets and workshops of China again sought fine jade. Once more, the famous jade road was opened.

Developments in Myanmar. Like China, Myanmar also was torn by political turmoil following World War II. In 1962, the Ne Win-led military junta seized power, plunging the country into isolation. The period 1963-64 saw the jadeite mines (along with most other mines, including those of the Mogok Stone Tract) placed off-limits to foreigners. By 1969, when the government banned private exploration and mining of gems, the isolation was complete (Mining Journal Annual Review, 1970).

After 1962, the only official sales of jadeite in then-Burma were at the annual gem emporiums held in the capital city of Rangoon (now Yangon). But most production reached the outside world via the black market. Lower grades tended to move directly into Yunnan, while top material was brought overland to the northern Thai town of Chiang Mai, where Hong Kong buyers assembled (Benjamin S. Y. So, pers. comm., 1997).

\section{LOCATION AND ACCESS}

Kyaukseinmyo (literally "Jade Land") is located in north-central Myanmar (again, see figure 2). The major jadeite mines are roughly enclosed east and west by the Uru (Uyu) and Chindwin rivers, between the 25th and 26th parallels of latitude, within Kachin State. (Because Myanmar names are often transliterated into the Roman alphabet in different ways, the authors have included common alternative spellings in parentheses. The first spellings given throughout the text are generally those of Chhibber, 1934b.) According to current information, the northernmost mines are near Kansi (Gin Si), while the southernmost are near Haungpa (Haung Par). The westernmost mine near Lai Sai (west of Tawmaw) is situated outside the central Jade Tract.

While Mogaung was formerly an important jadeite trading center, this is no longer the case. The present center of the mining district is Hpakan (Hpakant, Phakan, Phakant), a small town about
$16 \mathrm{~km}$ by road southeast of Tawmaw that lies along the Uru River. Tawmaw, the village adjacent to the most famous primary jadeite outcrop, lies some $120 \mathrm{~km}$ (75 miles) northwest of Mogaung. Other important towns in the area, also along the Uru River, include Lonkin (Lon Hkin) and Sate $\mathrm{Mu}$ (Seikmo, Sine Naung). The important mining town of Hwehka (Hweka) is located some $20 \mathrm{~km}$ due south of Hpakan, along the Hwe River (hka means river). Jadeite is also mined at Makapin (Makabin), just east of Hwehka. With the exception of Hwehka and Makapin, no jadeite mining takes place east of the Uru River.

Two major dirt roads lead into the mining district, one from Mogaung and the other (the more mountainous route) from Hopin (again, see figure 2). The authors traveled both routes-via modified trucks, cars, motorbikes, ponies, elephants, and on foot.

The area is a highly dissected upland, consisting of ranges of hills that form the Chindwin-Irrawaddy watershed (Chhibber, 1934b). Loimye Bum, an extinct volcano north of Kansi and the highest peak in the area, is $1,562 \mathrm{~m}$ above sea level. Tawmaw is $840 \mathrm{~m}$, and Hpakan is $350 \mathrm{~m}$, above sea level. The hills are covered with dense jungle. This is the area through which the Stillwell (Ledo) Road (Eldridge, 1946) was built, which was the scene of fierce fighting during World War II.

So brutal is the climate and so poor are the roads that travel is extremely difficult during the MayOctober monsoon season. Indeed, the November-April dry season is the only time one can be sure of reaching the mines. The authors' first trip, in early June 1996, took three days of struggling through mud to travel the approximately $56 \mathrm{~km}$ from Hopin to Hpakan, with a mere $8 \mathrm{~km}$ traveled on the second day. The return trip on the "good" road to Mogaung took more than 15 hours. At times during the rainy season, some areas are accessible only by foot, donkey, or elephant (figure 3). But the dry season has its challenges, too. Whereas by November the roads again become accessible by motor vehicle (eight hours for the Mogaung-Hpakan trip), the brown mud is transformed into dust clouds that cloak entire valleys.

Population. The population of Myanmar's Kachin State consists mainly of Shan, who dominate the major towns and valleys, and Kachin, who traditionally inhabit the hills (Hertz, 1912). The jade mines themselves feature a mixture of different peoples from around the country, lured by the promise of 


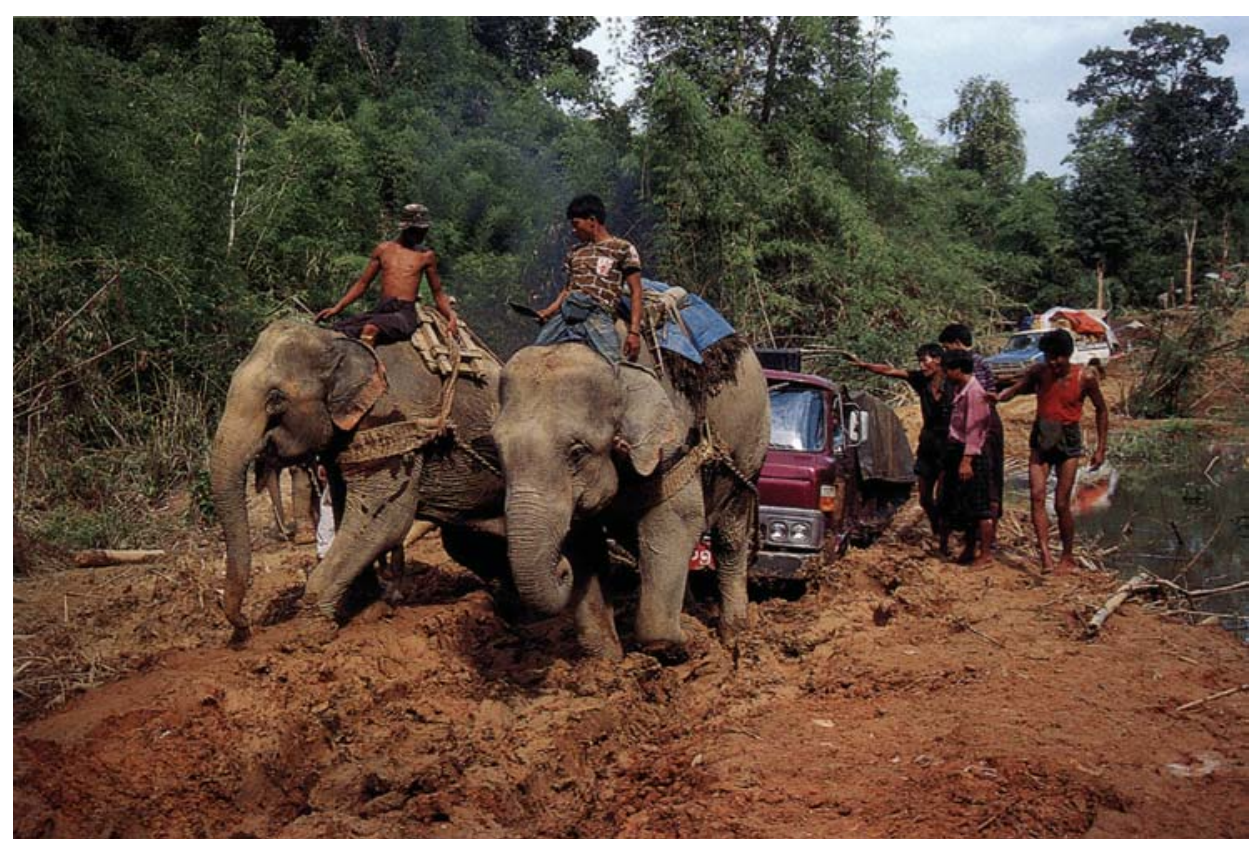

Figure 3. Both routes into Hpakan are virtually impassable during the rainy season. They require travel through dense jungle, in dirt that rapidly turns to mud. On this June 1996 trip, even the power of two elephants could not free this vehicle. Photo (C) Richard W. Hughes.

riches. During our visits to the mines, we met Kachin, Shan, Chinese, Chin, Wa, Rakhine, Nepalese, and Panthay. Today, however, immigrants from China increasingly dominate the towns and trade of northern Myanmar.

Hpakan today- "Little Hong Kong." Over the past few years, the Myanmar government has liberalized regulations concerning the gemstone sector, including the jade trade. For the first time in several decades, Myanmar citizens are allowed to trade in gems, and even to sell to foreigners ("Myanmar Gemstone Law," September 29, 1995). Nevertheless, conducting business in Myanmar continues to be difficult, especially for noncitizens.

Since the 1994 peace agreement between the Kachin rebel groups and the government, thousands of people from across Myanmar have flocked to the Hpakan area to look for jade. Like the gold rush towns of America's Old West, Hpakan and neighboring Sate $\mathrm{Mu}$ (Sine Naung) have a transient air. None of the many people we met had been at the mines for more than a decade, and most had been there less than a year. Likewise, none of the government or military officials encountered in 1996 was there nine months later.

Still, wealth lurks just below the surface, with satellite dishes sitting atop tin-roofed huts. Indeed, the locals refer to Hpakan as "little Hong Kong," because it is said that one can get anything there, including fine cognac, expensive watches, dancing girls, and heroin. It should be noted, too, that the area has a very high incidence of AIDS.

\section{GEOLOGY OF THE HPAKAN/TAWMAW AREA}

The first Western geologist to visit the mines was Fritz Noetling, who published his report in 1893. A.W.G. Bleeck followed with reports in 1907 and 1908. However, the most detailed account of the geology of the jadeite deposits is that of Harbans Lal Chhibber (1934a and b), who spent two years doing field work in the area, commencing in 1928. While substantial work has since been done by Myanmar geologists, little of this is available to Western scientists. Thus, Chhibber's reports remain the classic references on the subject. All those who have come after him, including Soe Win (1968), based their descriptions on Chhibber's publications.

The jadeite region, or Jade Tract, is situated in the low-altitude plateau-also referred to as the "26 $\mathrm{N}$ (latitude) high" (Bender, 1983)—formed by the Uru anticline (east of the Hkamti syncline), where basement rocks are exposed through the sediments of the Chindwin and Irrawaddy basins. The Jade Tract is characterized by bodies of serpentinized peridotite (between Late Cretaceous and Eocene age) in a broken outcropping from northernmost Maw Sit, through the Tawmaw area, to Makapin, Mohnyin (80 km south of Makapin), and Mawlu (35 km farther south). The serpentinites are surrounded by crystalline schists and plutonic rocks such as granites and monzonites (Bender, 1983), which were generated by subduction of the Indian plate under the Asian continent. In contrast, the peridotite was derived from either the base of the subducted oceanic plate or the mantle underlying the Asian plate, and emplaced by thrust faulting 


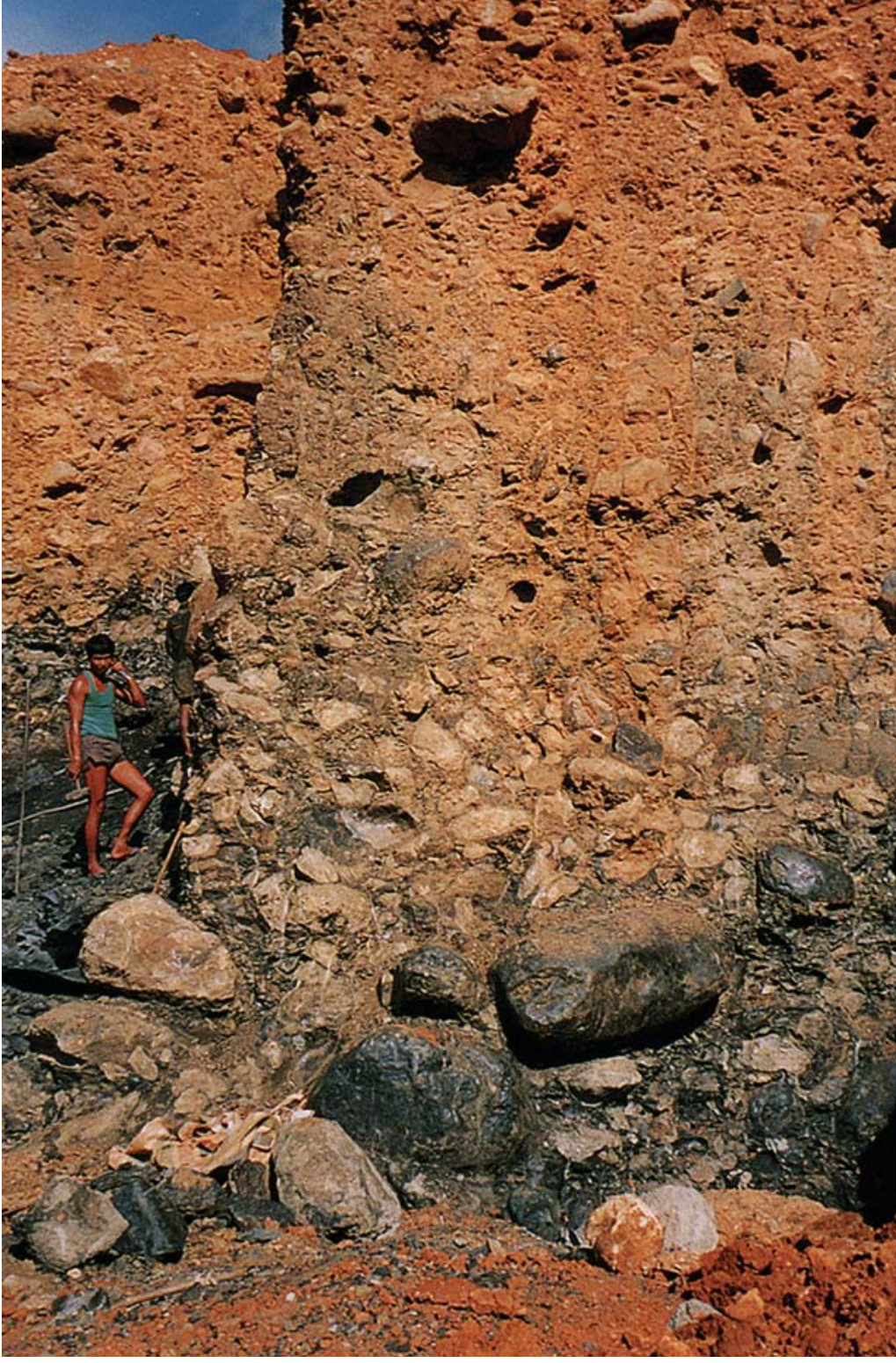

Figure 4. At the Ka Htan West mine, located between Lonkin and Tawmaw, large peridotite boulders can be seen at the base of this 15-m-high wall of Uru Boulder Conglomerate. Photo by George Bosshart.

(precursor of the Sagaing Fault) and uplift during the collision of the Indian subcontinent with Asia.

Jadeite formed independently of the intrusives by crystallization from hydrous fluids (derived by dewatering of the subducted Indian plate) that rose along fractures in the serpentinized peridotite at relatively high-pressure/low-temperature conditions during the Tertiary formation of the Himalayas (Bender, 1983). Fluids that form in these special conditions are saturated with respect to sodium aluminosilicates-jadeite at higher pressure, albite at lower pressure-so the passage of these fluids through serpentinites generated swarms of jadeitite, albite-nepheline, and albitite dikes. All of these dikes generally have central jadeite zones and external chlorite and amphibolite reaction rims at the contact with the serpentinites (Thin, 1985; Harlow and Olds, 1987; Sorensen and Harlow, 1998 and 1999). Chromite in the serpentinite locally reacted with the fluid to produce bright green (i.e., "Imperial") jadeite, usually only in latestage veins and as clots of green in white- to lavender-white jadeite. A shift from vertical thrusting to lateral faulting on the Sagaing Fault appears to have played an important role in the uplift and exposure of jadeite-bearing serpentinite in Myanmar; similar tectonics occurred in Guatemala, Japan, and Kazakhstan (Harlow and Sorensen, in press).

Primary Deposits. The classic primary occurrence of jadeite is on the plateau at Tawmaw. This area has been worked for over a hundred years and is said by miners to have produced all color varieties of jadeite. Other primary outcrops are found in the west, northwest, and northeast portions of the Jade Tract.

In each of the primary deposits, jadeitite dikes cross-cut the serpentinized peridotite parallel to shear zones following northeasterly strikes and dips from $18^{\circ}$ to $90^{\circ} \mathrm{SE}$. Dike thicknesses are poorly reported, probably because of weathering and the irregular swelling, pinching, and faulting-off of the dikes; however Soe Win (1968) does give a width of 5-8 feet $(1.5-2.5 \mathrm{~m})$ for the Khaisumaw dike at Tawmaw. Some dikes contain only jadeite and albite, while others have a boundary (on one or both sides) of amphibolite-eckermannite-glaucophane (dark gray to blue-black) or actinolite (dark green). The boundary with serpentinite is marked by a soft, green border zone that consists of a mixture of the adjacent vein minerals and chlorite, with or without calcite, actinolite, talc, and cherty masses (Chhibber, 1934b; Soe Win, 1968).

A Tawmaw mine director told GB and TO that the main dike was traceable north-northwest to Hkamti and Chindwin and even to India, surfacing and diving "like a serpent," with another branch running north to Putao. However, the recent visit to Hkamti (see pp. 14-15) and geologic constraints argue against this interpretation. Rather, the Jade Tract and Hkamti jadeite deposits appear to originate from separate, deep-seated serpentinite bodies that perhaps were derived from the same collisional process, and Putao appears to produce a different jade-like material, obviously with a different origin.

Secondary Deposits. Most jadeite is recovered from secondary deposits in the Uru Boulder Conglomerate 
At Hpakangyi, more than 10,000 workers excavated an area that had reached hundreds of meters deep (figure 8). Waste was piled into a waiting truck, and then emptied directly into the river that bisects Hpakan. At the dump, jade pickers scrambled over the riverbank to search for jade overlooked at the source. Along the banks of the Uru River, large mounds of boulders attest to two centuries of mining. When the water level is high, the river is worked by divers breathing via crude air pumps (figure 9).

Miners admitted that production was erratic at best. While occasionally they would find 20-30 pieces in a single day, often they would not recover any jadeite boulders for days. Most of these boulders weigh less than $1 \mathrm{~kg}$, although some reach $300 \mathrm{~kg}$. Only a tiny fraction of the jadeite boulders recovered contain jewelry-quality material.

Identifying Jadeite Boulders. After viewing the methods by which jade is mined, the first question any observer asks is: How do miners separate the occasional jadeite boulder from the thousands of other boulders that look so similar? Repeated questioning of various jade traders, cutters, and miners yielded the following clues.

The most important member of the mining team is the one who operates the jackhammer or hoe, for he will spot most of the jadeite boulders. When struck with a metal tool, a jadeite boulder produces a different sound (rings more) than other rocks. Such blows also may expose the "show points" (pyat kyet in Burmese and "pine flowers" to the Chinese; Gump, 1962)-the color of the jadeite-beneath the skin (figure 10).

Miners also look for a characteristic fibrous texture (yumm) in some jadeite boulders. Although jadeite jade is not normally thought of as having fibrous texture, it sometimes is found in jade that is $100 \%$ jadeitic pyroxene and in other cases may be related to partial replacement by-or admixture with —an amphibole (Htein and Naing, 1994, 1995). Also, jadeite is typically smoother than most other boulders and will not show the crystalline reflections (possibly from mica or quartz) often seen in the others. Another indicator of jadeite is a type of sheen, called shin. Black shin is said to "infect" or "damage" the stone; the miners consider it a harbinger of bad luck. According to Chhibber (1934b), shin is amphibolite or amphibole schist. Such an impurity would account for the lower quality of this jadeite.

Jadeite jade also has a greater "heft" (specific gravity of about 3.34 ) than other types of rocks in

Figure 10. Water readily reveals the "show points" of bright green jadeite on this boulder. Photo (C) Richard W. Hughes.

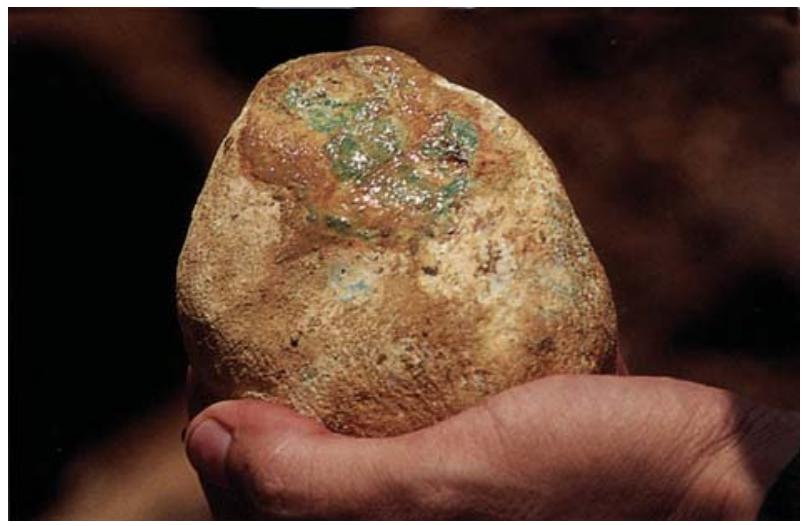




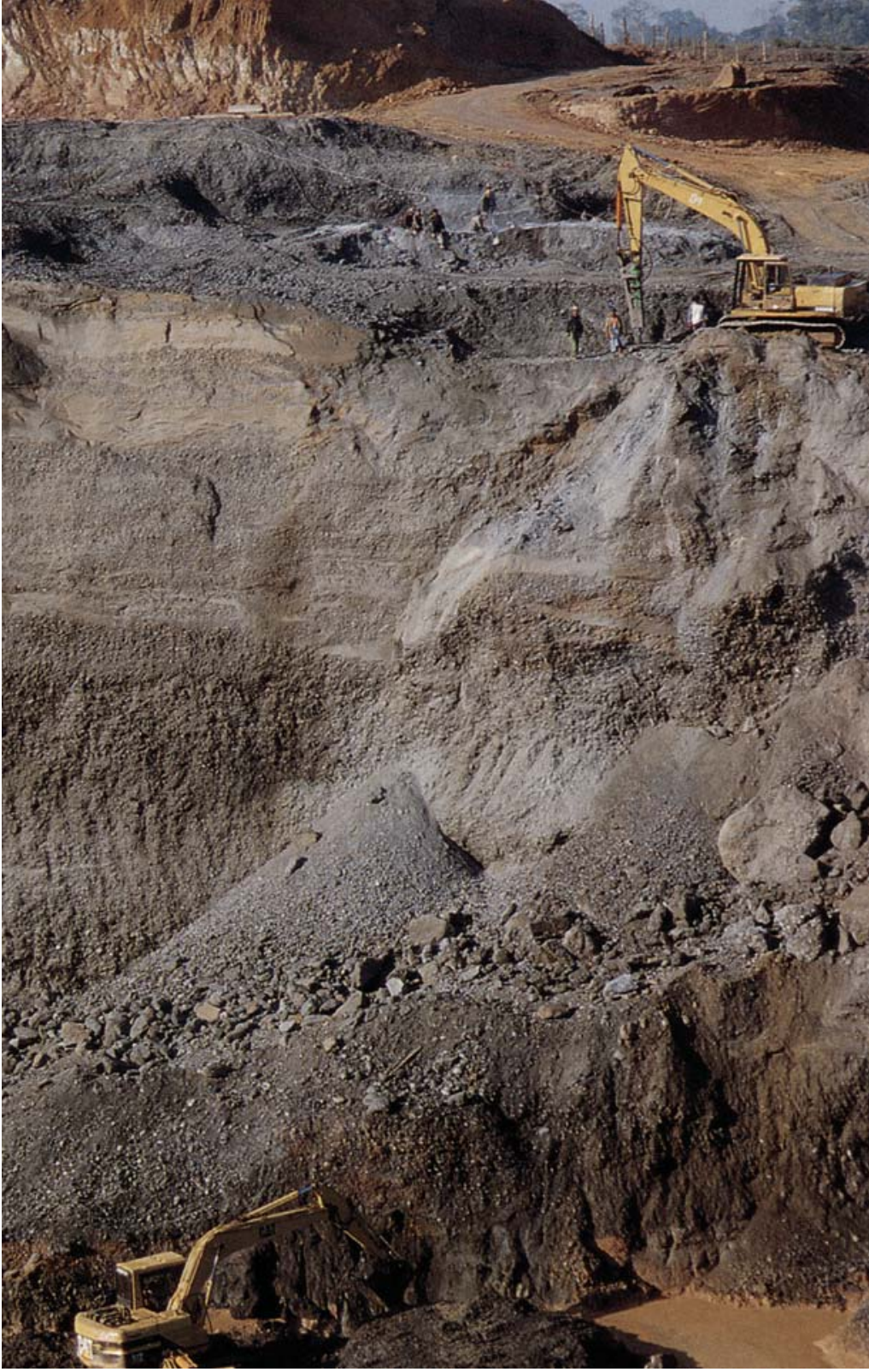

Figure 11. At Nansibon, backhoes are used to work the serpentinite boulder conglomerate in which jadeite boulders occur in narrow horizontal concentrations. Photo by George E. Harlow.

the conglomerate. In addition, divers feel that it sticks slightly to their hands or feet under water, a property that has been used historically by the Chinese to separate both jadeite and nephrite from substitutes ("The art of feeling jade," 1962).

Maw-Sit-Sit. The Maw Sit vein, which produces maw-sit-sit, lies about $2 \mathrm{~km}$ from Kansi at the northeastern end of the Jade Tract (again, see figure 2). The maw-sit-sit mine consists of a narrow, vertical trench cut that is some $9 \mathrm{~m}$ deep. The total length of the active mining area in November 1997 was approximately $200 \mathrm{~m}$.

\section{OTHER JADEITE LOCALITIES IN MYANMAR}

According to Chhibber (1934b), other occurrences of jadeite in present-day Myanmar include Mawhun, $20 \mathrm{~km}$ southwest of Mohnyin, and a site on the bank of the Chindwin River, in the Hkamti area. It is possible that the latter reference is actually to the Nansibon mining region, described below, which was recently visited by one of the authors (GEH). The United Nations (1979) reported the extraction of low-quality jade from steeply dipping late-Tertiary boulder conglomerates in the IndawTigyang area, which extends another $50 \mathrm{~km}$ south of Mawhun. Similar conglomerates were observed at Nansibon (again, see below).

Hkamti Area: Nansibon and Natmaw. On an expedition to the jade mines by a group traveling under the auspices of the American Museum of Natural History in January and February 2000, four geologists and two gemologists visited the mining area called Nansibon (Namsibum, Manhsibon). It was the first recorded visit by Western gemologists to this area. Located in the Sagaing Division, about 35 $\mathrm{km}$ (22 miles) southeast of the Chindwin River town of Hkamti, Nansibon is a group of joint-venture tracts that extend about $2 \mathrm{~km}$ along a northsouth trending ridge in the middle of dense jungle (central location at N25 51'24", E95 $51^{\prime} 30^{\prime \prime}$ determined by GPS measurements). The deposit is a steeply inclined $\left(60^{\circ}-90^{\circ} \mathrm{E}\right)$ serpentinite boulder conglomerate in which jadeite cobbles from a few centimeters to perhaps one meter in diameter are "concentrated" in a few narrow horizons. Mining is restricted to mechanized excavation of surface exposures of the conglomerate (figure 11), which disappears both north and south under Tertiary river sands and lake sediments of the Chindwin basin. Now largely unworked, Natmaw (Nawmaw, Nathmaw) is a smaller area roughly $30 \mathrm{~km}$ south of Nansibon, where miners have explored jadeite dikes in serpentinite. As the road there was impassable and time was constrained, the group could not visit these latter mines.

According to current and retired officials from the Myanma Gems Enterprise (MGE), relative to the Jade Tract, Nansibon presently produces a large portion of the gem-quality Imperial jadeite mined in Myanmar, lesser amounts of other colors and "commercial" jadeite (used for carvings and bangles), and small amounts of "utility" jade (used for tiles, building veneers, and very large carvings; "Myanma jade," 1991). During the recent visit, GEH and gem- 
$10 \%$ of the appraised value. Even though a boulder has been officially appraised, its purchase is inevitably a gamble for the trader.

Types of Jadeite Rough. Traders classify jadeite rough first according to where it was mined. River jade, the jadeite recovered from alluvial deposits in and along the Uru River, occurs as rounded boulders with a thin skin (figure 14, top left). In contrast, mountain jade (found away from the river) appears as rounded boulders with thick skins (figure 14, bottom left). The irregular chunks of jadeite quarried directly from in situ deposits, such as those at Tawmaw, represent a third type (figure 14, right). According to Chhibber (1934b), "it is locally believed that jadeite mined from the rivers and conglomerate is more "mature' than that of Tawmaw."
Because weathering usually removes damaged or altered areas, the best qualities are usually associated with river jade. In addition, the thin skinand, therefore, greater likelihood of "show points"-in river jade allows a more accurate estimate of the quality and color within (figure 10). Mountain jade boulders tend to be clouded by a thick layer (termed "mist" by Chinese traders) between the skin and the inner portion of the boulder (Ho, 1996; figure 14).

The occurrence of green and lavender jadeite is independent of the deposit type, but reddish orange to brown jadeite is found only in those boulders that are recovered from an iron-rich soil. The reddish orange results from a natural iron-oxide staining of the skin of the porous jadeite, and is sometimes intensified with heat (Chhibber, 1934b).

Figure 14. Top left: This jadeite boulder shows the relatively thin skin and potentially good color that is usually associated with "river jade." Although from the outside this appears to be a normal jadeite boulder, oxidants that entered through cracks on the surface have produced a large area of discoloration. Bottom left: Note the thick yellow "mist" around the jadeite in this boulder of "mountain jade." Right: A key advantage to jadeite taken from in situ deposits is that the quality of the material is readily apparent. Photos () Richard W. Hughes.
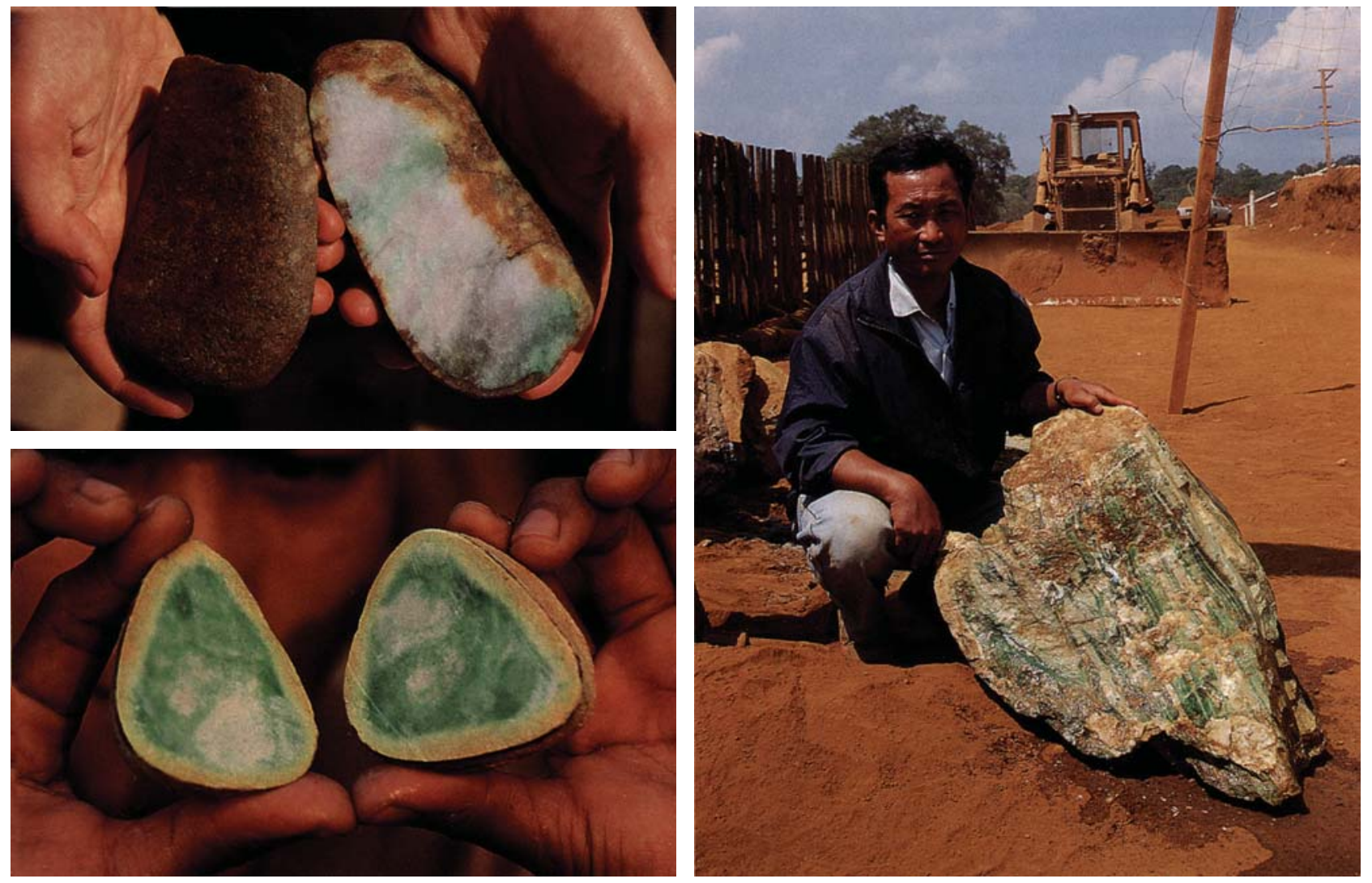


\section{EVALUATING ROUGH}

One of the greatest challenges in the jadeite trade is the evaluation of a material that is covered by a skin that typically hides all traces of the color and clarity/diaphaneity that lies within. This skin can be white, yellow, light to dark brown, or black.

According to traders and miners with whom we spoke, they look first for any color spots or show points in those areas where the skin is thin enough to see through. Evidence of surface cracks is also important, as fractures often extend into the boulder and open a path for oxidants to discolor the interior (see figure 14, top left). Such fractures can have a strong negative impact on the value of the material.

If a show point is not available or is inadequate, the owner will sometimes polish an "eye" or maw ("cut" or "window") through the skin (see figure 1). First, though, the owner will carefully examine the piece to determine the best location because, if good color shows through the window, the boulder's value rises tremendously. Conversely, if poor color is revealed, the value drops. Such windows should be checked for artificial coatings or other tampering, which may give a false impression of the material within (see, e.g., Johnson and Koivula, 1998).

If there are no show points or windows, a common technique is to wet the surface of the boulder in the hope that the underlying color will come through (again, see figure 10). Where even a little color is suggested, traders also use small metal plates in conjunction with a penlight. They place the edge of the plate on what appears to be a promising area and then shine the penlight from the side farthest from the eye (figure 15). The plate removes the glare from the light, so any color can show through. If light penetrates the underlying jadeite, this is an indication of good transparency. But, due to jadeite's aggregate structure, the color will have been diffused from throughout the boulder by the scattering of light. Thus, even a small area of rich color can make a piece appear attractive through the window. To see an example of this, take a jadeite cabochon that is white, but has a small green vein or spot. Shine a penlight or fiberoptic light through the cab from behind. Voilà, the entire cabochon appears green.

To reduce the risk of such a speculative business, much jadeite rough is simply sawn in half; this is the approach used at the government-sponsored auctions in Yangon. However, parting a boulder down the middle has the danger of cutting right through the center of a good area. A more careful

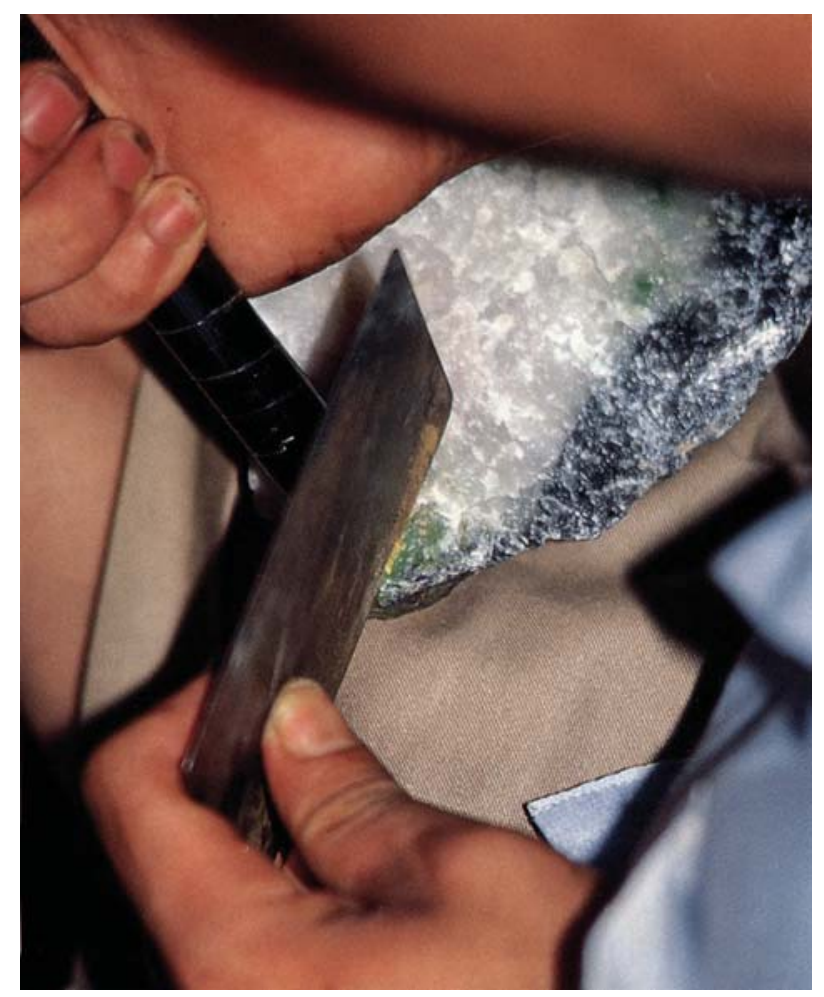

Figure 15. To get a better idea of the quality of color in this boulder, the dealer places a metal plate at the far side of a small area with potential and then uses a penlight to illuminate it. Photo (C) Richard W. Hughes.

method of evaluating jadeite boulders involves grinding away the skin (Lee, 1956). Alternatively, some owners gradually slice the boulder from one end (perhaps the thickness of a bangle, so that each slice can be used for bangles or cabochons) until they hit good color. They then repeat the process from the opposite end, the top, and the bottom, until the area of best color is isolated (figure 16).

Certain experienced jade traders are said to have a "golden hand" when it comes to judging jade boulders; that is, they are able to predict, by studying the outside of the boulder, what the inner color will be. Nevertheless, the jade trade seems to be a competition between sellers, who want to show the best spot of color and not disclose the remaining bad points, and buyers, who want to imagine a fine interior in a stone that shows poorly in the few maws.

\section{EVALUATION OF FINISHED JADEITE}

The evaluation of finished jadeite has been discussed by Healy and Yu (1983), Ng and Root (1984), and, most recently, by Christie's (1995b), Ho (1996), 


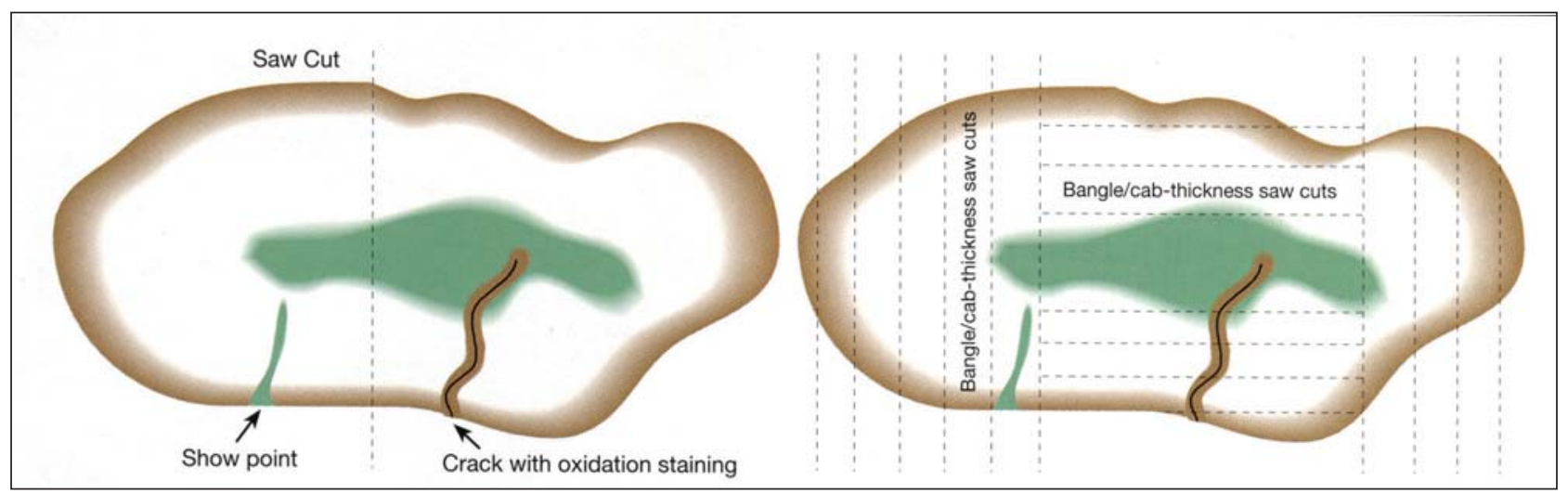

Figure 16. In sawing jadeite boulders, center saw cuts (left) run the risk of cutting through a valuable area. A better method (right) involves making shallow saw cuts from one end (perhaps the thickness of a bangle, so that each slice can be used for bangles/cabs) until one hits good color. Then the process is repeated from the opposite end, again until good color is encountered. This defines the region of top-grade material. The process is repeated until the area of best color is isolated. These cross-sections also illustrate a show point and an oxidation stain penetrating the jadeite through a crack.

and Ou Yang $(1995,1999)$. The basic system is summarized below in a somewhat simplified fashion. Although we use the concepts discussed in the above publications, as much as possible we have chosen language that is comparable to that used for other colored stones.

While a number of fanciful terms have been used to describe jadeite, its evaluation is similar to that of other gemstones in that it is based primarily on the "Three Cs" - color, clarity, and cut (fashioning). Unlike most colored stones, the fourth " $\mathrm{C}$ "—carat weight-is less important than the dimensions of the fashioned piece. However, two additional factors are also considered-the "Two Ts" - translucency (diaphaneity) and texture. In the following discussion, Chinese terms for some of the key factors are given in parentheses, with a complete list of Chinese terms for various aspects of jade given in table 1.

Color (se). This is the most important factor in the quality of fashioned jadeite. As per standard color nomenclature, jadeite's colors are best described by breaking them down into the three color components: hue (position on the color wheel), saturation (intensity), and tone (lightness or darkness). Color distribution must also be taken into account. The necklace in figure 17 is an excellent example of top-quality hue, saturation, tone, and color distribution.

- Hue (zheng): Top-quality jadeite is pure green. While its hue position is usually slightly more yellow than that of fine emerald and it never quite reaches the same intensity of color, the ideal for jadeite is a fine "emerald" green. No brown or gray
TABLE 1. Chinese jade nomenclature ${ }^{a}$.

\begin{tabular}{|c|c|}
\hline $\begin{array}{l}\text { Chinese } \\
\text { name }\end{array}$ & Meaning \\
\hline Yu & Chinese word for jade \\
\hline Ruan yu & Nephrite \\
\hline Ying yu & "Hard jade" or jadeite \\
\hline $\begin{array}{l}\text { Fei-ts'ui } \\
\text { (feicui) }\end{array}$ & "Kingfisher" jadeite \\
\hline Lao keng & "Old mine" jadeite-fine texture \\
\hline Jiu keng & "Relatively old mine" jadeite-medium texture \\
\hline Xin keng & "New mine" jadeite—coarse texture \\
\hline Ying & $\begin{array}{l}\text { Jadeite type with the highest luster and } \\
\text { transparency }\end{array}$ \\
\hline $\begin{array}{l}\text { Guan yin } \\
\text { zhong }\end{array}$ & Semi-translucent, even, pale green jadeite \\
\hline $\begin{array}{l}\text { Hong wu } \\
\text { dong }\end{array}$ & $\begin{array}{l}\text { Lesser quality than guan yin zhong, with a pale red } \\
\text { mixed with the green }\end{array}$ \\
\hline Jin si zhong & $\begin{array}{l}\text { "Golden thread" jadeite: A vivid green color is } \\
\text { spread evenly throughout the stone. This type is } \\
\text { quite valuable. }\end{array}$ \\
\hline Zi er cui & $\begin{array}{l}\text { High-grade jadeite mined from rivers. Because of } \\
\text { its high translucency, it is also known as bing } \\
\text { zhong ("ice"). }\end{array}$ \\
\hline $\begin{array}{l}\text { Lao keng bo } \\
\text { li zhong }\end{array}$ & $\begin{array}{l}\text { Old-mine "glassy" (finer texture, more translucent) } \\
\text { jadeite (see figure 18). In Imperial green, this type is } \\
\text { the most valuable jadeite. }\end{array}$ \\
\hline Fei yu & Red jadeite, named after a red-feathered bird \\
\hline Hong pi & $\begin{array}{l}\text { "Red skin" jadeite, cut from the red skin of a } \\
\text { boulder (see figure 1) }\end{array}$ \\
\hline Jin fei cui & Golden or yellow jadeite \\
\hline Shuangxi & Jadeite with both red and green \\
\hline Fu lu shou & Jadeite with red, green, and lavender \\
\hline Da si $x i$ & $\begin{array}{l}\text { Highly translucent jadeite with red, green, lavender, } \\
\text { and yellow }\end{array}$ \\
\hline Wufu linmen & $\begin{array}{l}\text { Jadeite with red, green, lavender, and yellow, as } \\
\text { well as white as the bottom layer }\end{array}$ \\
\hline
\end{tabular}

${ }^{a}$ Based on Ho (1996). 
modifiers should be present in the finished piece.

- Saturation (nong): This is by far the most important element of green and lavender jadeite color. The finest colors appear intense from a distance (sometimes described as "penetrating"). Side-byside comparisons are essential to judge saturation accurately. Generally, the more saturated the hue is, the more valuable the stone will be. A related factor is referred to as cui by the Chinese. Colors with fine cui are variously described as brilliant, sharp, bright, or hot. This is the quality that makes "shocking" pink shocking and "electric" blue electric.

- Tone (xian): The ideal tone is medium-not too light or too dark.

- Distribution (jun): Ideally, color should be completely even to the unaided eye, without spotting or veins. In lower qualities, fine root- or vein-like structures that contrast with the bodycolor of the stone may be considered attractive. However, dull veins or roots are less desirable. Any form of mottling, dark irregular specks, or blotches that detract from the overall appearance of the stone will reduce the value.

Clarity. This refers to imperfections that impair the passage of light. The finest jadeite has no inclusions or other clarity defects that are visible to the naked eye.

Typical imperfections are mineral inclusions, which usually are black, dark green, or brown, but may be other colors. White spots also are common, as are other intergrown minerals. The most severe clarity defects in jadeite are fractures (healed or unhealed), which can have an enormous impact on value because jadeite symbolizes durability and perfection (Ou Yang, 1999).

Translucency (Diaphaneity). This is another important factor in evaluating quality. The best jadeite is semi-transparent; opaque jadeite or material with cloudy patches typically has the least value.

It is interesting to note that even if the overall color is uneven or low in saturation, jadeite can still be quite valuable if it has good transparency. The "glass" jade bangles in figure 18 sold for U.S. $\$ 116,000$ at the November 1999 Christie's Hong Kong auction.

Texture (zhong). In jadeite, texture is intimately related to transparency. In the authors' experience, typically the finer the texture is, the higher the

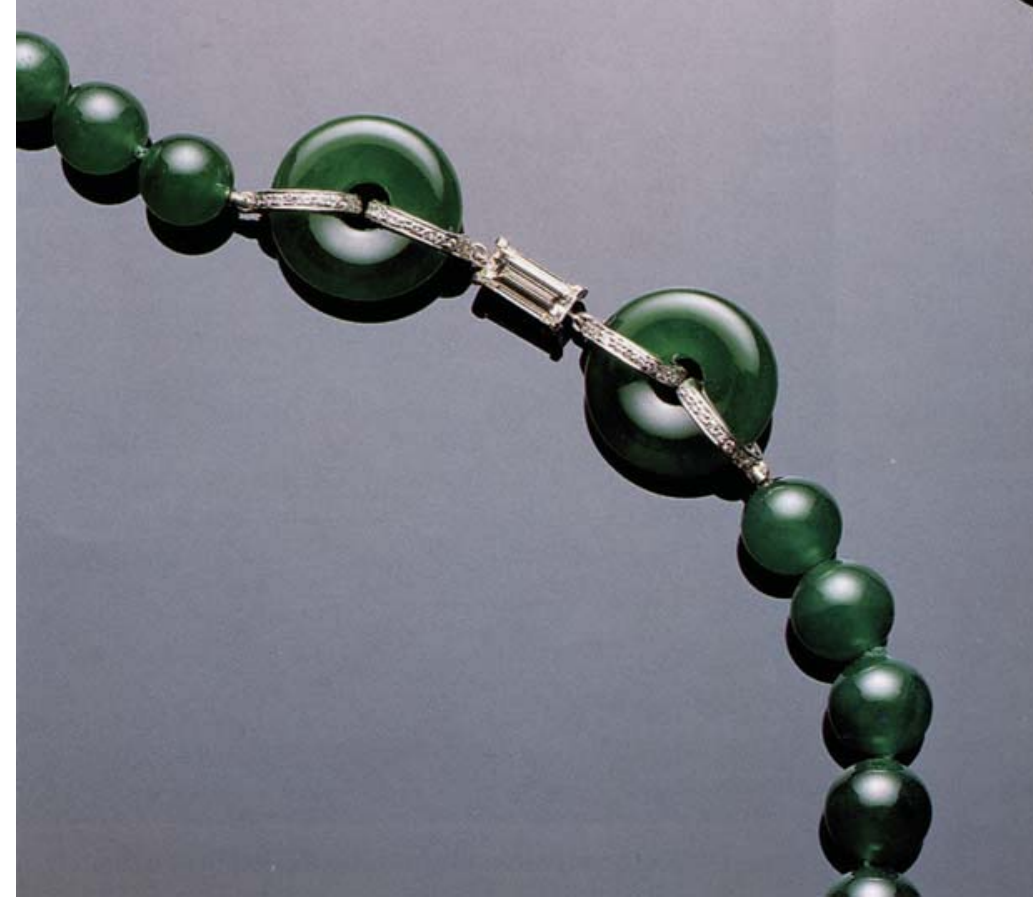

Figure 17. This necklace, which contains a total of 65 beads (7.8-9.8 $\mathrm{mm}$ in diameter) and two matching hoops, illustrates the optimum "vivid emerald green" color in fine jadeite. Note also the very fine "old mine" texture and translucency. Photo courtesy of and (c) Christie's Hong Kong and Tino Hammid.

transparency will be. Further, the evenness of the transparency depends on the consistency of the grain size. Our observations also suggest that coarse-grained jadeite tends to have more irregularities, blotches, or discolorations.

Texture is key to the classification of fashioned jadeite into three categories: fine (lao keng, or "old mine"), medium (jiu keng, or "relatively old mine"), and coarse (xin keng, or "new mine"), as described by Ho (1996). "Old mine" is considered the best, with the finest texture, translucency, and luster (again, see figures 17 and 18). Note that Chinese jadeite dealers also use the terms "old mine" (keng zhong) and "new mine" (xin shan zi) to describe rough. This is not really an expression of the age or location where the jadeite is mined, but more an indication of texture and translucency, with oldmine jadeite having a higher quality, being of finer grain size, and having greater luster and translucency (Ho, 1996). It probably derives from the belief that jade that is more compact and of finer texture is of greater age. 


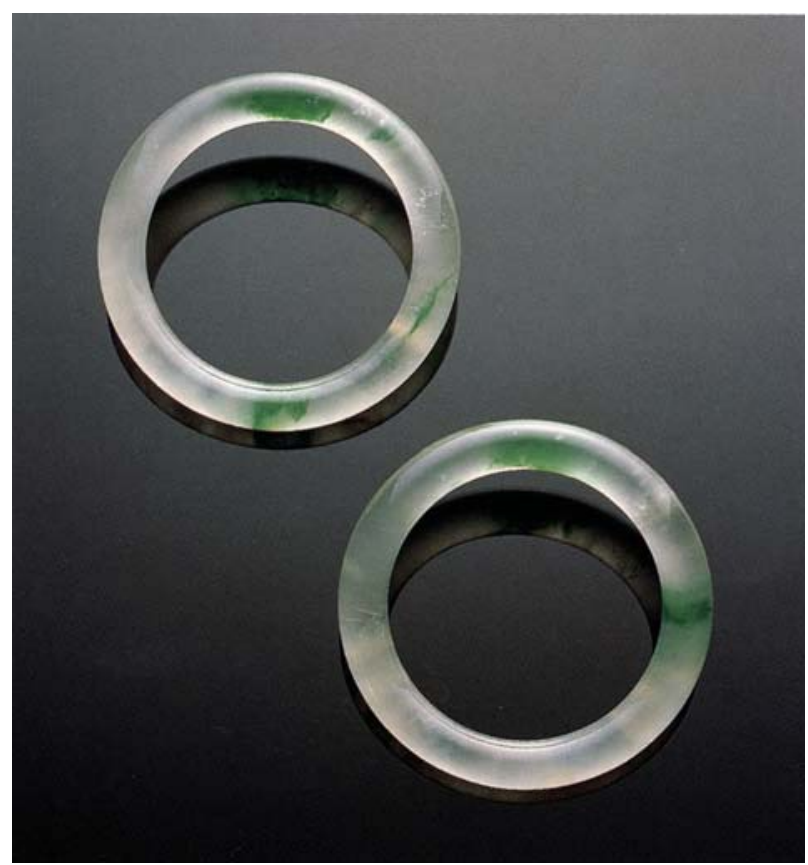

Figure 18. Referred to as "glass" jadeite, this rare pair of bangles (both $53.4 \mathrm{~mm}$ in interior diameter, with thicknesses of 9.6 and $9.7 \mathrm{~mm}$ ) shows extraordinary translucency. Photo courtesy of and (c) Christie's Hong Kong and Tino Hammid.

Fashioning. More so than for most gem materials, fashioning plays a critical role in jadeite beauty and value. Typically, the finest qualities are cut for use in jewelry-as cabochons, bracelets, or beads. Cutters often specialize: one may do rings, another carvings, and so on.

Polish is particularly important with jadeite. Fine polish results in fine luster, so that light can pass cleanly in and out of a translucent or semi- transparent piece. One method of judging the quality of polish is to examine the reflection of a beam of light on the surface of a piece of jadeite. A stone with fine polish will produce a sharp, undistorted reflection, with no "orange-peel" or dimpling visible.

Following are a few of the more popular cutting styles of jadeite.

Cabochons. The finer qualities are usually cut as cabochons (see figure 1). One of the premium sizes - the standard used by many dealers' price guides-is $14 \times 10 \mathrm{~mm}$ (Samuel Kung, pers. comm., 1997). Material used for cabochons is generally of higher quality than that used for carvings (Ou Yang, 1999), although there are exceptions.

With cabochons, the key factors in evaluating cut are the contour of the dome, the symmetry and proportions of the cabochon, and its thickness. Cabochon domes should be smoothly curved, not too high or too flat, and should have no irregular flat spots. Proportions should be well balanced, not too narrow or wide, with a pleasing length-to-width ratio (Ng and Root, 1984). The best-cut cabochons have no flaws or unevenness of color that is visible to the unaided eye.

Since the 1930s, double cabochons, shaped like the Chinese ginko nut, have been considered the ideal for top-grade jadeite, since the convex bottom is said to increase light return to the eye, thus intensifying color (Christie's, 1996). Stones with poor transparency, however, are best cut with flat bases, since any material below the girdle just adds to the bulk without increasing beauty. Hollow cabochons are considered least valuable (Ou Yang, 1999).

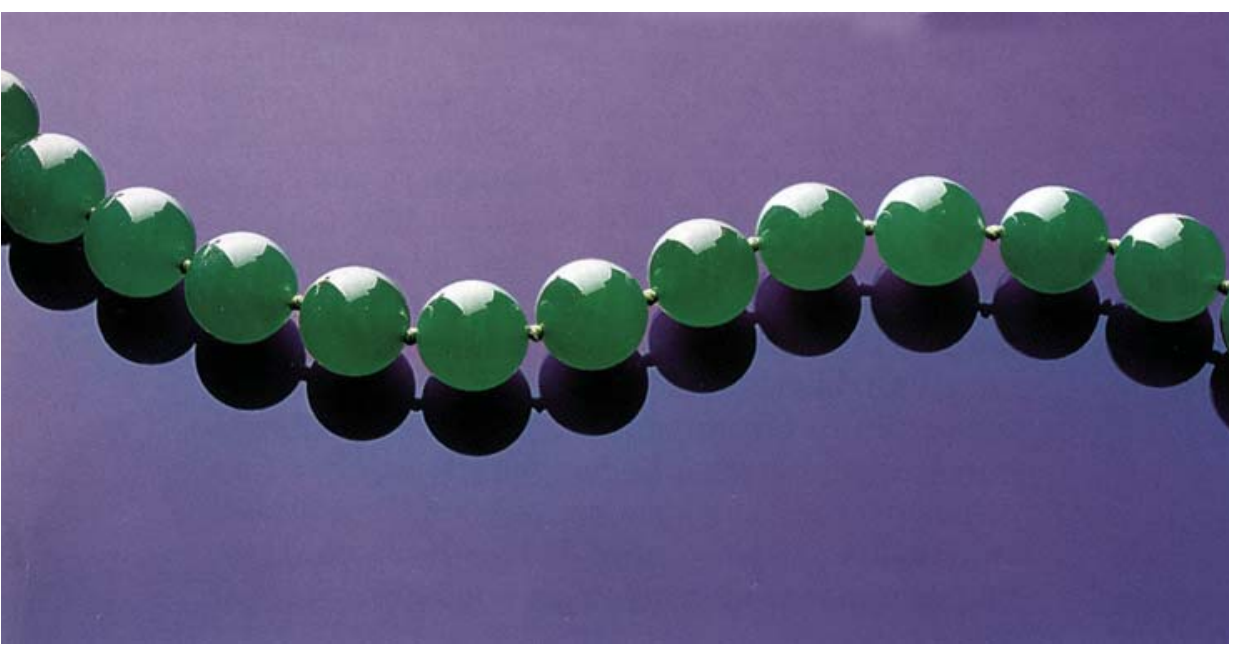

Figure 19. Uniformity of a fine "emerald" green color, superb translucency, size, and symmetry all come together to produce the necklace known as the Doubly Fortunate. The 27 beads, which range from $15.09-15.84 \mathrm{~mm}$, were all cut from the same piece of rough, a $1 \mathrm{~kg}$ portion of a much larger boulder. The name derived from the fact that the necklace's owners "doubled their fortunes" every time the boulder was cut (Christie's, 1997, p. 70). The necklace sold in 1997 for approximately US\$9.3 million. Photo courtesy of and (c) Christie's Hong Kong and Tino Hammid. 
Traditionally, when fine jadeite cabochons are mounted in jewelry, they are backed by metal with a small hole in the center. The metal acts as a foilback of sorts, increasing light return from the stone. Also, with the hole one can shine a penlight through the stone to examine the interior, or probe the back with a toothpick to determine the contours of the cabochon base (Ng and Root, 1984). When this hole is not present, one needs to take extra care, as the metal may be hiding some defect or deception.

Beads. Strands of uniform jadeite beads are in greater demand than those with graduated beads. The precision with which the beads are matched for color and texture is particularly important, with greater uniformity resulting in greater value (figure 19). Other factors include the roundness of the beads and the symmetry of the drill holes. Because of the difficulties involved in matching color, longer strands and larger beads will carry significantly higher values. Beads should be closely examined for cracks. Those cracked beads of $15 \mathrm{~mm}$ diameter or greater may be recut into cabochons, which usually carry a higher value than a flawed bead $(\mathrm{Ng}$ and Root, 1984).

Bangle Bracelets. Bangles are one of the most popular forms of jadeite jewelry, symbolizing unity and eternity. Even today, it is widely believed in the Orient that a bangle will protect its wearer from disaster by absorbing negative influences. For example, if the wearer is caught in an accident, the bangle will break so that its owner will remain unharmed. Another common belief is that a spot of fine color in a bangle may spread across the entire stone, depending on the fuqi-good fortune - of the owner (Christie's, 1995a). In the past, bangles (and rings) were often made in pairs, in the belief that good things always come in twos (Christie's, 1997).

Because a single-piece bangle requires a large quantity of jadeite relative to its yield, prices can be quite high, particularly for fine-quality material. The bangle in figure 20 sold for US\$2,576,600 at the Christie's Hong Kong November 1999 auction. Multi-piece bangles are worth less than those fashioned from a single piece, because the former often represent a method of recovering parts of a broken bangle. Mottled material is generally used for carved bangles, as the carving will hide or disguise the imperfections. When a piece is carved from highquality material, however, it can be a true collector's item (Ng and Root, 1984).

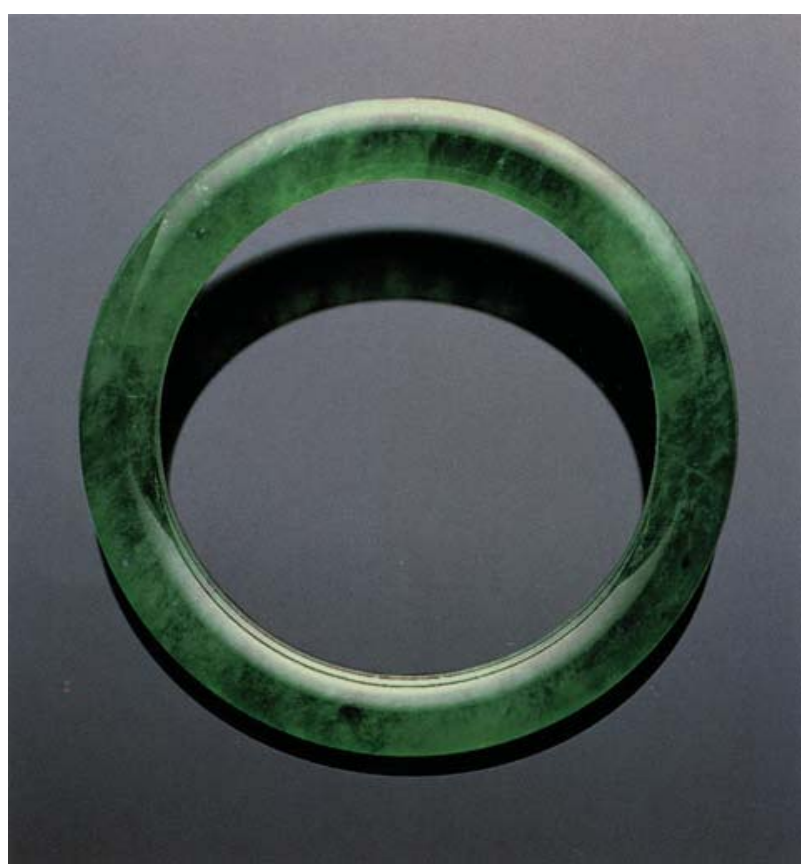

Figure 20. Believed to date back at least four millenia in China, the jade bangle is both one of the oldest and one of the most important pieces of jewelry in the Chinese culture. This superb jadeite bangle sold for US\$2,576,600 at the Christie's Hong Kong November 1999 auction. The interior diameter is $49.50 \mathrm{~mm}$; the jadeite is $8.36 \mathrm{~mm}$ thick. Photo courtesy of and (C) Christie's Hong Kong and Tino Hammid.

Huaigu (pi). The Chinese symbol of eternity, this is a flat disk with a hole in its center, usually mounted as a pendant or brooch. Ideally, the hole should be one-fifth the diameter of the entire disk and exactly centered. Small pairs are often used in earrings or cufflinks (figure 21).

Saddle Rings (su an). Carved from a single piece of jadeite, these look like a simple jadeite band onto which a cabochon has been directly cut (figure 22). Saddle rings allow the most beautiful area to be positioned on top of the ring, while the lower part is relatively hidden, whereas a standard jadeite band should have uniform color all around. Saddle tops are the top piece of a saddle ring, without the band portion (again, see figure 21).

Double Hoop Earrings (lian huan). These require a large amount of rough relative to their yield, since they are cut from two pieces of the same quality, each of which must produce two hoops. A pair of these earrings (figure 23) sold for US\$1.55 million at Christie's April 29, 1997, Hong Kong sale (Christie's, 1997). 


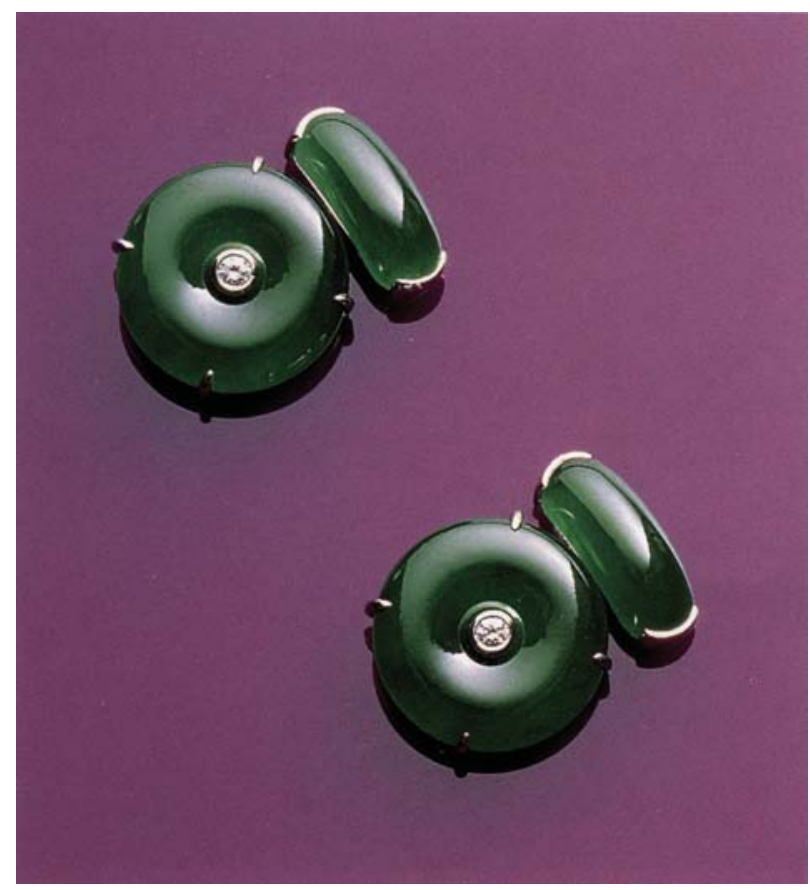

Figure 21. These fine matched huaigu (each approximately $19 \times 4.5 \mathrm{~mm}$ ) have been set as cufflinks, with diamonds inserted into their center holes. Each is linked to a saddle top of comparable material. Photo courtesy of and (c) Christie's Hong Kong and Tino Hammid.

Carvings. For the most part, the jadeite used in carvings is of lower quality than that used for other cutting styles, but nevertheless there are some spectacular carved jadeite pendants and objets d'art. The intricacy of the design and the skill with which it is executed are significant factors in determining the value of the piece. Carving is certainly one area where the whole equals more than the sum of the parts.

Recut Recovery Potential. As with many other types of gems, the value of poorly cut or damaged pieces is generally based on their recut potential. For example, it might be possible to cut a broken bangle into several cabochons. Thus, the value of the broken bangle would be the value of the cabochons into which it was recut ( $\mathrm{Ng}$ and Root, 1984). If three cabochons worth $\$ 500$ each could be cut from the bangle, its value would be about $\$ 1,500$.

Enhancements and Imitations. Enhancements. Jadeite historically has been subjected to various enhancements to "finish" it, "clean" surface and interior stains, and even dye it to change the color altogether. In recent years, a three-part-A through
C-classification system has been used in Hong Kong and elsewhere to designate the treatment to which an item has been subjected (Fritsch et al., 1992).

A-Jade is jadeite that has not been treated in any way other than cutting and polishing. Surface waxing is generally considered part of the "traditional" finishing process. Used to improve luster and fill surface fractures and pits, wax dipping is the final step in finishing virtually all cut jadeite (figure 24).

As noted above, much jadeite is discolored by rust-like oxidation stains. B-Jade is jadeite that has been soaked in chemical bleaches and/or acids for an extended period to remove brown or yellow impurities from between grain boundaries and cracks. Because this treatment process leaves voids in the jadeite, the bleached jadeite is subsequently impregnated with paraffin wax or, most commonly, a clear polymer resin. The result is usually a significant improvement in both transparency and color. However, detection of this enhancement requires infrared spectroscopy, a sophisticated technique that usually must be performed in a gemological laboratory. (See Fritsch et al., 1992, for a full description of both the treatment and its identification.)

Figure 22. Note the small patches of a slightly paler color on the shank of one of these "emerald" green saddle rings $(21.27$ and $21.65 \mathrm{~mm}$, respectively, in longest dimension). Photo courtesy of and (c) Christie's Hong Kong and Tino Hammid.

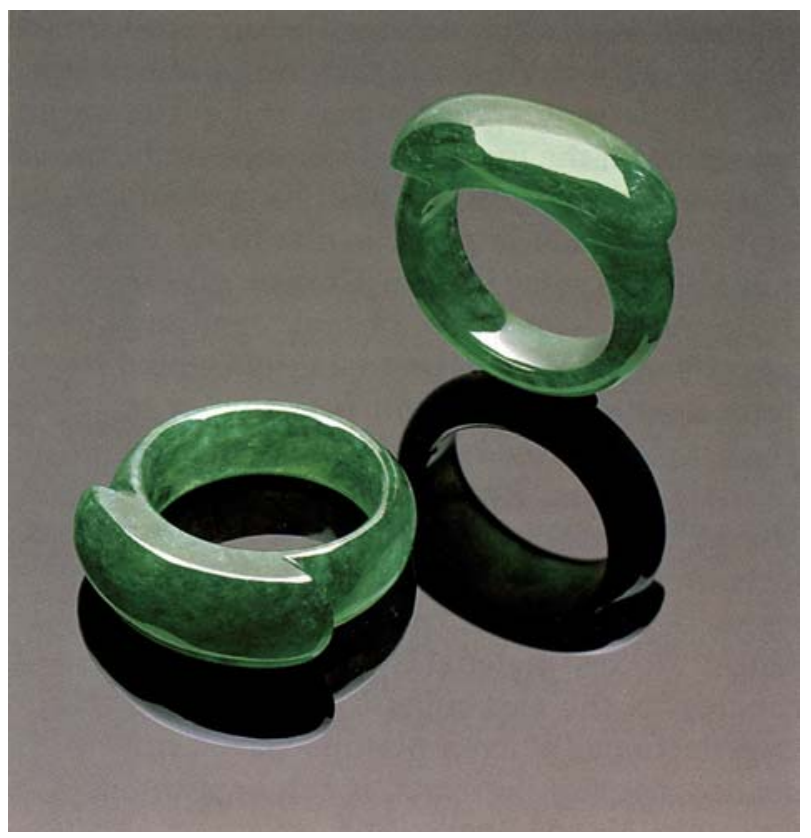


C-Jade, jadeite that has been artificially stained or dyed, also has a long history. Green, lavender, and even orange-brown (Wu, 1997) colors are produced by staining suitable pale-colored material with vegetable or other organic dyes, a process that has been performed on jadeite since at least the 1950s. The methods used in Hong Kong have been described by Ehrmann (1958), Ng and Root (1984), and Ho (1996).

The authors have seen fading in both dyed green and dyed lavender jades, but the green dyes tend to fade more readily. Generally, dyeing is identified with a microscope and a spectroscope: The color tends to concentrate in veins throughout the stone, in surface cracks, and along grain boundaries; also, a broad band from about 630 to $670 \mathrm{~nm}$ in the red region of the visible spectrum is considered proof of dye in green jadeite (see, e.g., Hobbs, 1982). Some of the newer dyes may also show a weaker band at 600 $\mathrm{nm}$. Because some stones are only partially dyed, the entire piece must be checked.

Assembled Stones and Other Imitations. There are many assembled stones that resemble jadeite. These include triplets made by taking a highly translucent piece of pale-colored jadeite and cutting it as a thin, hollow cabochon. A second cabochon is cut to fit snugly into the first, with a green cement or jellylike substance placed between the two. A third, flat piece of jadeite of lower transparency is then cemented onto the base. Another type of assembled stone is that made with a piece of extremely dark green jadeite hollowed out to eggshell thickness. This allows light to pass through, creating the appearance of fine Imperial jade. To strengthen the piece, the hollow back is filled with an epoxy-like substance; and to hide the deception, the piece is then mounted in jewelry with the back hidden (Kammerling and McClure, 1995; Hughes and Slavens, 1999).

At Mandalay's jadeite market, two of the authors (RWH and FW) noticed many pale jadeite cabochons that had been coated on their upper surface with green plastic (Hughes, 1987). Another convincing imitation is produced by first placing a dye layer on the piece and then overlaying it with varnish (Koivula et al., 1994).

Repairs. Bangles in particular that have been broken during wear are sometimes cleverly reassembled with glue. UV fluorescence is a good method of detecting such fraud, since the glues often fluoresce

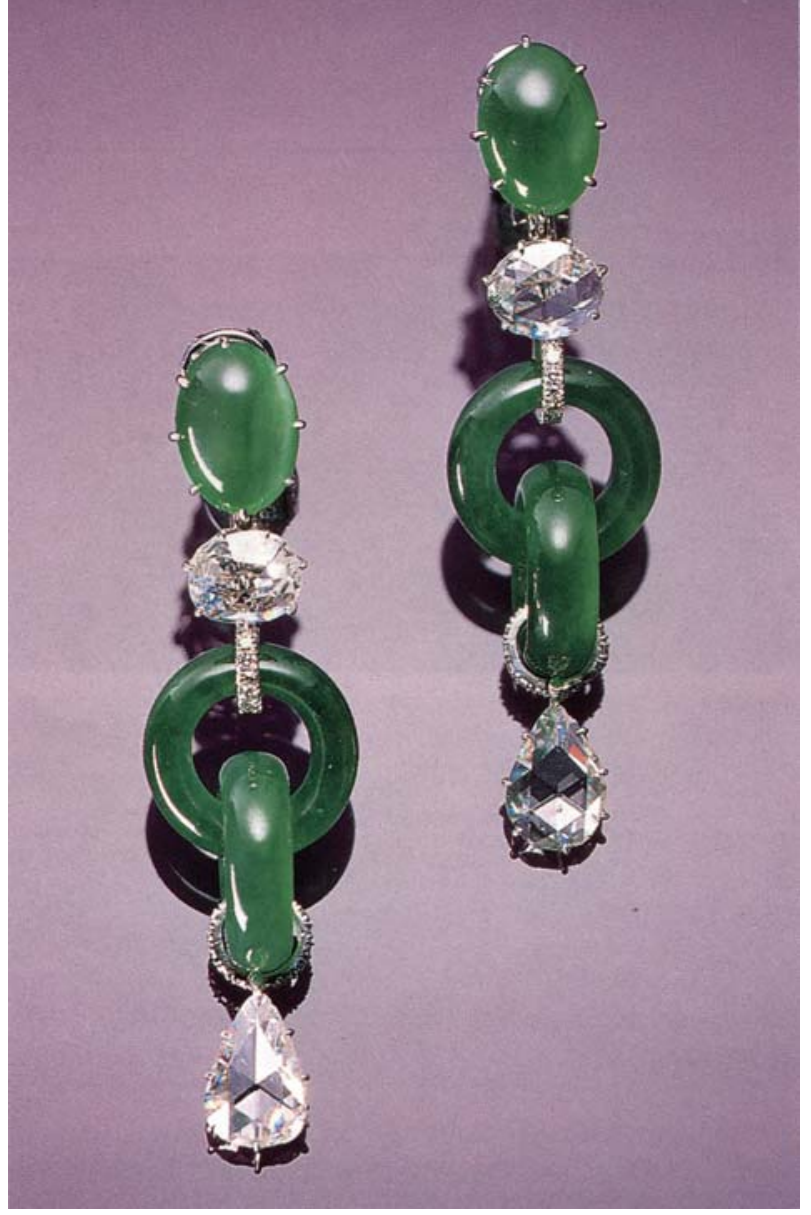

Figure 23. The well-matched hoops and cabochons in these double hoop earrings set with rose-cut diamonds have been dated to the Qing dynasty (1644-1912). They sold for US\$1.55 million in 1997. Courtesy of Christie's Hong Kong; photo by Tino Hammid.

(commonly blue; DelRe, 1992). Gas bubbles also may be seen in the cement portions (Hughes and Slavens, 1999).

Assembled Rough. The authors have observed several types of assembled rough. One type involves grinding away the skin of a jade boulder, painting or staining the surface green, and then "growing" a new skin via immersion in chemicals, which deposit a new oxidation layer on the outside. Unlike the skin on genuine jadeite boulders, which is extremely tough and can be removed only by grinding, the fake skins are soft and easily taken off. Another type involves sawing or drilling a core out of a jade boulder, inserting a green filling and a reflector, and then covering the hole with a combination of epoxy and grindings from the surface of jade boulders.

In certain cases, even the cut windows of jadeite boulders may be faked. One method involves simply 

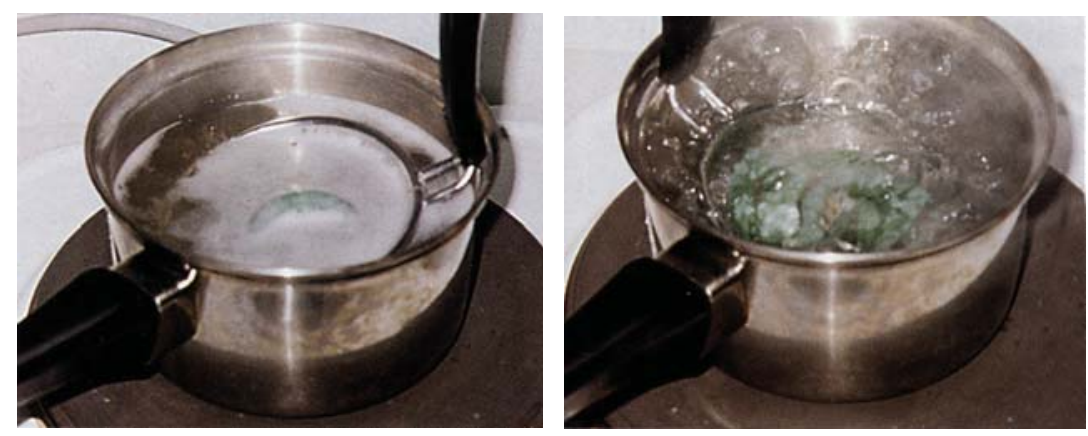

Figure 24. A process commonly used to enhance polished jadeite, waxing (or "wax dipping") is actually a simple procedure. First (top left), the bangles are soaked in a warm alkaline solution about 5-10 minutes to clean the residue left behind during polishing. Next they are rinsed, dried, and then soaked in an acidic "plum sauce" to remove any residue from the alkaline solution. Then, they are rinsed, dried, and placed in boiling

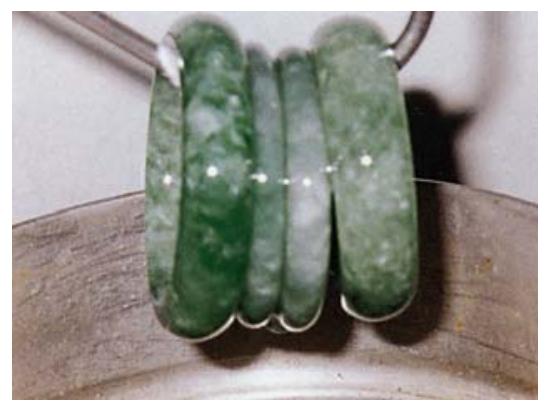

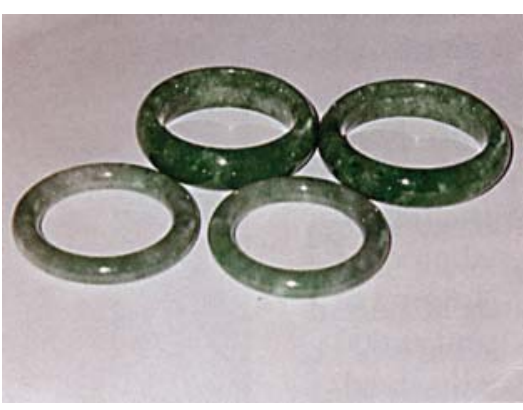
water for several minutes (top right) to open the "pores" in the jadeite and bring it to the right temperature (to avoid cracking) before it is placed in a pre-melted wax solution for several minutes to several hours (bottom left). After waxing, the items are polished with a clean cloth to reveal their best luster (bottom right). Photos and description by Benjamin So.

applying a superficial stain to the window area. Another is to break off a chip, stain it green and glue it back onto the boulder. When a window is then cut on the boulder, it "reveals" a fine green color.

\section{JADEITE AUCTIONS}

At many of the early auctions, buyers would examine the jade and make offers to the seller using hand signals under a handkerchief (see, e.g., Ng and Root, 1984, for an illustration of these "finger signs"). This system, which has been used historically at the mines as well as in China, allows the seller to realize the highest price for each lot without letting others know the actual amount paid. Thus, the buyer can resell the material at whatever price the market will bear (Allan K. C. Lam, pers. comm., 1997). This technique can still be seen every morning in Hong Kong's Canton Road jade market. However, it is no longer used at the jadeite mines.

Recognizing the importance of the market for jadeite jewelry, Sotheby's Hong Kong initiated specialized jadeite jewelry auctions in November 1985 with just 25 pieces. Christie's Hong Kong followed suit in 1994 with a sale of 100 pieces. Since then, thousands of pieces have been auctioned off by Christie's Hong Kong in what are now biannual auctions of magnificent jadeite jewelry.

To give some idea of the importance of this market, the Mdivani necklace (Lot 898), which contains 27 beads (15.4 to $19.2 \mathrm{~mm}$ in diameter), sold for US\$3.88 million at the October 1994, Christie's Hong Kong sale. The record price for a single piece of jadeite jewelry was set at the November 1997 Christie's Hong Kong sale: Lot 1843 , the "Doubly Fortunate" necklace of 27 approximately $15 \mathrm{~mm}$ jadeite beads, sold for US $\$ 9.3$ million (again, see figure 19). These auctions clearly show that jadeite is among the most valuable of all gemstones.

\section{SUMMARY AND CONCLUSION}

Jade (primarily nephrite) has been prized in China for thousands of years. Yet the finest jadejadeite-has been a part of the Chinese culture only since the late 18th century, when the mines in what is today north-central Myanmar were opened. As the first Western gemologists to enter the remote jadeite mining area in more than three decades, the authors witnessed tens of thousands of miners working the rivers, Uru conglomerate, and in-situ deposits in search of jadeite. Backhoes, trucks, pneumatic drills, and rudimentary tools are all enlisted in the different mining operations.

Identification of jadeite in a boulder requires both luck and skill (and the presence of windows or "eyes"), although many dealers simply grind off the skin of the boulder or cut it in half. Once the taxes are paid (and the boulders marked accordingly), the rough jadeite is sold primarily to Chinese buyers who carry it to Hong Kong and elsewhere 
in China for resale and fashioning. Color, clarity, transparency, and texture are the key considerations in evaluating fine jadeite, which is cut into many different forms - such as cabochons, bangles, saddle rings, disks, and double hoop earrings, as well as carved for use as pendants or objets d'art.

The finest Imperial jadeite is a rich "emerald" green color that is highly translucent to semi-transparent, with a good luster. With both rough and fashioned jadeite, purchasers must be cautious about manufactured samples or enhancements. Although "waxing" of jadeite has been an accepted practice for many years, the more recent " $\mathrm{B}$ " jadeby which the stone is cleaned with acid and then impregnated with a paraffin wax or polymer-will affect the value of the piece. Jadeite is often dyed, and plastic-coated cabochons were seen even in the Myanmar markets. Also of concern, because of durability, are those jadeite pieces that have been cut very thin and then "backed" or filled with an epoxy-like substance.

The prices received at the Hong Kong auctions held specifically for jade indicate that for many people, especially in the Orient, jadeite holds a higher value than almost any other gem material. From humble beginnings as an encrusted boulder to its exquisite emergence as a fashioned piece, jadeite truly is an inscrutable gem.
Acknowledgments: Richard Hughes thanks Robert Weldon and Jewelers' Circular-Keystone for making his first trip possible. Thanks also to Robert Frey for a careful reading of the manuscript, Elaine FerrariSanthon of the Richard T. Liddicoat Library and Information Center for helpful research on jade, and Dr. Edward Gübelin, whose earlier accounts of the mines provided inspiration. Olivier Galibert thanks the following: C. K. Chan of Chow Tai Fook, Edmond Chin of Christie's Hong Kong, Garry Dutoit of the AGTA Gemological Testing Center, Lisa Hubbard of Sotheby's Hong Kong, Benjamin So and Judith Grieder Jacobs of the Hong Kong Jade and Jewellery Association, Samuel Kung, Dominic Mok, and Eric Nussbaum of Cartier Geneva. George Bosshart thanks his wife, Anne, an outstanding trekking companion. Fred Ward and Richard Hughes thank Georg Muller, television producer and friend with enough foresight, insight, and connections to get his colleagues and himself into the Myanmar jade localities. George Harlow and Richard Hughes also thank William Larson of Pala International for his help and advice. Photographer Tino Hammid was very helpful in providing photos of the Christie's Hong Kong auction items, and Harold and Erica Van Pelt supplied figures 1 and B-3, as well as the cover.

This article is dedicated to our colleague and coauthor, Dr. Thet Oo, who suffered a series of strokes after his second trip to the mines. A finer traveling companion does not exist. We wish him a speedy recovery.

\section{REFERENCES}

The art of feeling jade (1962) The Gemmologist, Vol. 31, No. 372, pp. 131-133 (reprinted from Gems and Minerals, No. 286, July 1961, pp. 28-29).

Bender F. (1983) Geology of Burma. Gebrüder Borntraeger, Berlin, $260 \mathrm{pp}$.

Bleeck A.W.G. (1907) Die Jadeitlagerstätten in Upper Burma. Zeitschrift für praktische Geologie, Vol. 15, pp. 341-365.

Bleeck A.W.G. (1908) Jadeite in the Kachin Hills, Upper Burma. Records, Geological Survey of India, Vol. 36, No. 4, pp. 254-285.

Chhibber H.L. (1934a) The Geology of Burma. Macmillan, London, $538 \mathrm{pp}$.

Chhibber H.L. (1934b) The Mineral Resources of Burma. Macmillan, London, $320 \mathrm{pp}$.

Christie's (1995a) Magnificent Jadeite Jewellery. Catalog for Christie's Hong Kong, May 1, 1995 auction.

Christie's (1995b) Magnificent Jadeite Jewellery. Catalog for Christie's Hong Kong, October 30, 1995 auction.

Christie's (1996) Magnificent Jadeite Jewellery. Catalog for Christie's Hong Kong, November 5, 1996 auction.

Christie's (1997) Magnificent Jadeite Jewellery. Catalog for Christie's Hong Kong, April 29, 1997 auction.

Cummings J., Wheeler T. (1996) Lonely Planet Travel
Survival Kit: Myanmar (Burma), 6th. ed. Lonely Planet, Hawthorn, Australia, 393 pp.

Damour A. (1863) Notice et analyse sur le jade vert: réunion de cette matière minérale à la famille des wernerites. Comptes Rendus des Séances de l'Académie des Sciences, Vol. 56, pp. 861-865.

Deer W.A., Howie R.A., Zussman J. (1963) Rock-forming Minerals. Vol. 2, Chain Silicates. John Wiley and Sons, New York.

DelRe N. (1992) Gem Trade Lab notes: Repaired jadeite. Gems ef Gemology, Vol. 28, No. 3, pp. 193-194.

Ehrmann M.L. (1958) A new look in jade. Gems ↔) Gemology, Vol. 9, No. 5, pp. 134-135, 158.

Eldridge F. (1946) Wrath in Burma, 1st ed. Doubleday \& Co., Garden City, NY, 320 pp.

Fritsch E., Wu S.-T.T., Moses T., McClure S.F., Moon M. (1992) Identification of bleached and polymer-impregnated jadeite. Gems « Gemology, Vol. 28, No. 3, pp. 176-187.

Goette J. (n.d.) Jade Lore. Reynal \& Hitchcock, New York, $321 \mathrm{pp}$.

Griffith W. (1847) Journals of Travels in Assam, Burma, Bootan, Affghanistan, and the Neighbouring Countries. Bishop's College Press, Calcutta, reprinted in 1971 by Ch'eng Wen Publishing Co., Taipei, 529 pp. 
Gübelin E.J. (1964-65) Maw-sit-sit: A new decorative gemstone from Burma. Gems \&) Gemology, Vol. 11, No. 8, pp. 227-238, 255 .

Gübelin E.J. (1965a) Jadealbit: Ein neuer Schmuckstein aus Burma. Zeitschrift der Deutschen Gesellschaft für Edelsteinkunde, No. 51, pp. 4-22.

Gübelin E.J. (1965b) Maw-sit-sit-A new decorative gemstone from Burma. Journal of Gemmology, Vol. 9, No. 10, pp. 329-344.

Gübelin E.J. (1965c) Maw-sit-sit proves to be jade-albite. Journal of Gemmology, Vol. 9, No. 11, pp. 372-379.

Gump R. (1962) Jade: Stone of Heaven. Doubleday \& Co., Garden City, NY, 260 pp.

Hänni H.A., Meyer J. (1997) Maw-sit-sit (kosmochlore jade): A metamorphic rock with a complex composition from Myanmar (Burma). Proceedings of the 26th International Gemmological Conference, Idar-Oberstein, Germany, pp. $22-24$.

Hansford S.H. (1950) Chinese Jade Carving, 1st ed. Lund Humphries \& Co., London, 145 pp.

Harlow G.E., Olds E.P. (1987) Observations on terrestrial ureyite and ureyitic pyroxene. American Mineralogist, Vol. 72, pp. 126-136.

Harlow G.E., Sorensen S.S. (in press) Jade: Occurrence and metasomatic origin. Extended Abstracts of the 25th International Geological Congress, August 2000, Rio de Janeiro, Brazil.

Healy D., Yu R.M. (1983) Quality grading of jadeite. Lapidary Journal, Vol. 36, No. 10, pp. 1670-1674.

Hertz W.A. (1912) Burma Gazetteer: Myitkyina District. Superintendent, Government Printing and Stationery, Rangoon, Volume A, reprinted 1960, 193 pp.

Hind Co. Map (1945) Mogaung Sheet, Hind 1095 Sheet 92C, First Edition Unlayered.

Ho L.Y. (1996) Jadeite, English ed. Transl. by G.B. Choo, Asiapac, Singapore, $127 \mathrm{pp}$.

Hobbs J.M. (1982) The jade enigma. Gems ↔ Gemology, Vol. 18, No. 1, pp. 3-19.

Htein W., Naing A.M. (1994) Mineral and chemical compositions of jadeite jade of Myanmar. Journal of Gemmology, Vol. 24, No. 4, pp. 269-276.

Htein W., Naing A.M. (1995) Studies on kosmochlor, jadeite and associated minerals in jade of Myanmar. Journal of Gemmology, Vol. 24, No. 5, pp. 315-320.

Hughes R.W. (1987) The plastic coating of gemstones. Australian Gemmologist, Vol. 16, No. 7, pp. 259-261.

Hughes R.W. (1999) Burma's jade mines: An annotated occidental history. Journal of the Geo-Literary Society, Vol. 14, No. 1, pp. 15-35.

Hughes R.W., Slavens C. (1999) Tales from the Crypt-GQI lab news: Jadeite-Repaired, assembled, treated. GQ Eye, Vol. 2, No. 1, pp. 10-11.

Jackson J.A., Ed. (1997) Glossary of Geology, 4th ed. American Geological Institute, Alexandria, VA, $769 \mathrm{pp}$

Johnson M.L., Koivula J.I., Eds. (1998) Gem news: Jadeite boulder fakes. Gems ↔ Gemology, Vol. 34, No. 2, pp. 141-142.

Kammerling R.C., Koivula J.I., Johnson M.L., Eds. (1995) Gem news: Jade market in Mandalay. Gems \& Gemology, Vol. 31, No. 4, pp. 278-279.

Kammerling R.C., McClure S.F. (1995) Gem Trade Lab notes: Jadeite jade assemblages. Gems $\nrightarrow$ Gemology, Vol. 31, No. 3, pp. 199-201.

Keller P.C. (1990) Gemstones and Their Origins. Van Nostrand Reinhold, New York, 144 pp.
Koivula J.I., Kammerling R.C., Fritsch E., Eds. (1994): Gem news: Coated jadeite. Gems e) Gemology, Vol. 30, No. 3, p. 199.

Lee R. (1956) Jade cutting in Orient. The Mineralogist, Vol. 24, No. 3, March, pp. 138-140.

Lintner B. (1994) Burma in Revolt. Westview Press, Boulder, $\mathrm{CO}, 514 \mathrm{pp}$.

Lintner B. (1996) Land of Jade: A Journey from India through Northern Burma to China, 2nd rev. ed. White Orchid Press, Bangkok, 380 pp.

Mével C., Kiénast J.R. (1986) Jadeite-kosmochlor solid solution and chromian sodic amphiboles in jadeitites and associated rocks from Tawmaw (Burma). Bulletin de Minéralogie, Vol. 109, pp. 617-633.

Mining Journal Annual Review (1970) Diamonds, gemstones and abrasives: Other gemstones. Mining Journal, London, June, p. 124.

Morimoto N., Fabries J., et al. (1988) Nomenclature of pyroxenes. American Mineralogist, Vol. 73, pp. 1123-1133.

Myanma jade (1991) Myanma Gems Enterprise, WPD, Yangon, unpublished report.

Ng J.Y., Root E. (1984) Jade for You: Value Guide to Fine Jewelry Jade. Jade N Gem Corp. of America, Los Angeles, CA, $107 \mathrm{pp}$.

Noetling F. (1893) Note on the occurrence of jadeite in Upper Burma. Records, Geological Survey of India, Vol. 26, pp. 26-31.

Ou Yang C.M. (1993) Microscopic studies of Burmese jadeite jade-1. Journal of Gemmology, Vol. 23, No. 5, pp. 278-284.

Ou Yang C.M. (1995) Jadeite Appreciation. Cosmos Books Ltd., Hong Kong, 191 pp. [in Chinese].

Ou Yang C.M. (1999) How to make an appraisal of jadeite. Australian Gemmologist, Vol. 20, No. 5, pp. 188-192.

Ponahlo J. (1999) Cathodoluminescence du jade. Revue de Gemmologie A.F.G., No. 137, pp. 10-16.

Rossman G.R. (1974) Lavender jade: The optical spectrum of $\mathrm{Fe}^{3+}$ and $\mathrm{Fe}^{2+}-\mathrm{Fe}^{3+}$ inter-valence charge transfer in jadeite from Burma. American Mineralogist, Vol. 59, pp. 868-870.

Soe Win (1968) The application of geology to the mining of jade. Union of Burma Journal of Science and Technology, Vol. 1, pp. 445-456.

Sorensen S.S., Harlow G.E. (1998) A cathodoluminescence (CL)guided ion and electron microprobe tour of jadeitite chemistry and petrogenesis. Abstracts with Programs, 1998 Annual Meeting, Geological Society of America, Vol. 30, p. A-60.

Sorensen S.S., Harlow G.E. (1999) The geochemical evolution of jadeitite-depositing fluids. Abstracts with Programs, Annual Meeting of the Geological Society of America, Vol. 31, p. A101.

Thin N. (1985) Petrologic-Tectonic Environment of Jade Deposits, Phakant-Tawmaw Jade Tract, Burma. Department of Geology, University of Rangoon.

Tröger W.E. (1967) Optische Bestimmung der gesteinsbildenden Minerale. E. Schweizer-bart'sche Verlagsbuchhandlung, Stuttgart, Teil 2.

United Nations (1979) Geological Mapping and Geochemical Exploration in Mansi-Manhton, Indaw-Tigyaing, KyindweLongyi, Patchaung-Yane and Yezin Areas, Burma. Mineral Exploration Burma, Technical Report 7, United Nations Development Programme, 13 pp., 6 maps in body.

Wang C. (1994) Essence and nomenclature of jade-A problem revisited. Bulletin of the Friends of Jade, Vol. 8, pp. 55-66.

Wu S.T. (1997) The identification of $\mathrm{B}+\mathrm{C}$ jade. Journal of the Gemmological Association of Hong Kong, Vol. 20, pp. 27-29. 